\title{
Hughes v. Oklahoma: The Court, the Commerce Clause, and State Control of Natural Resources
}

Walter Hellerstein

University of Georgia School of Law, wallyh@uga.edu

Prepress SSRN

\section{Repository Citation}

Walter Hellerstein, Hughes v. Oklahoma: The Court, the Commerce Clause, and State Control of Natural Resources (1979),

Available at: https://digitalcommons.law.uga.edu/fac_artchop/485

This Article is brought to you for free and open access by the Faculty Scholarship at Digital Commons @ University of Georgia School of Law. It has been accepted for inclusion in Scholarly Works by an authorized administrator of Digital Commons @ University of Georgia School of Law. Please share how you have benefited from this access For more information, please contact tstriepe@uga.edu. 
HUGHES v. OKLAHOMA: THE COURT, THE COMMERCE CLAUSE, AND STATE CONTROL OF NATURAL RESOURCES

The Supreme Court's recent Commerce Clause opinions reflect an apparent effort to rationalize and modernize the analytical framework for delineating the implied restraints that the Clause imposes on state legislation. In the state tax field, the Court has articulated a coherent set of criteria controlling the validity of state taxes on interstate commerce $e^{1}$ and has discarded doctrine inconsistent with these standards. ${ }^{2}$ In the state regulatory context, the Court has likewise enunciated meaningful decisional principles governing the con-

Walter Hellerstein is Associate Professor of Law at the University of Georgia.

AuthoR's Nore: The author would like to thank Gregory S. Alexander, Jerome R. Hellerstein, Paul M. Kurtz, D. Robert Lohn, and Michael Wells for their helpful comments on an earlier draft of this article.

1 Japan Line, Ltd. v. County of Los Angeles, 99 S. Ct. 1813, 1819-20 (1979); Department of Revenue v. Association of Washington Stevedoring Cos., 435 U.S. 734, 750 (1978); Complete Auto Transit, Inc. v. Brady, 430 U.S. 274, 279, 287 (1977); Colonial Pipeline Co. v. Traigle, 421 U.S. 100, 108 (1975). See also note 80 infra.

${ }^{2}$ Department of Revenue v. Association of Washington Stevedoring Cos., 435 U.S. 734 (1978), overruling Joseph v. Carter \& Weekes Stevedoring Co., 330 U.S. 422 (1947), and Puget Sound Stevedoring Co. v. State Tax Commission, 302 U.S. 90 (1937); Complete Auto Transit, Inc. v. Brady, 430 U.S. 274 (1977), overruling Spector Motor Service, Inc. v. O'Connor, 340 U.S. 602 (1951).

(C) 1980 by The University of Chicago. 0-226-46432-6/80/1979-0005\$03.26 
stitutionality of state regulations affecting interstate commerce ${ }^{3}$ and has applied them without substantial concern for their impact on its precedents of an earlier era. ${ }^{4}$ To be sure, not all of the Court's contemporary Commerce Clause opinions fit easily into the suggested pattern, ${ }^{5}$ and what appears as a clear pattern may be only a haphazard arrangement. Hughes $v$. Oklaboma ${ }^{6}$ emerges, however, as yet another piece in the developing mosaic of the Court's Commerce Clause jurisprudence.

\section{The Hughes Decision}

\section{A. THE FACTS AND PROCEEDINGS BELOW}

The essential facts in the case were simple and undisputed. Through its Wildlife Conservation Code, ${ }^{7}$ Oklahoma had established a statutory scheme governing the acquisition, transportation, and sale of minnows in the State. The Code provided for the licensing of persons seeking to seine, transport, or sell minnows in the State for commercial purposes. ${ }^{8}$ It imposed no restriction on the number of minnows a person so licensed was permitted to take from state waters. The Code stipulated, however, that "[n]o person may transport or ship minnows for sale outside the state which were seined or procured within the waters of this state." The prohibition was inapplicable to persons "leaving the state possessing three (3) dozen or less minnows" or to the "sale and shipment of minnows raised in a regularly licensed commercial minnow hatchery." 10 In substance, then, the statute forbade the transportation for out-of-state

\footnotetext{
${ }^{3}$ City of Philadelphia v. New Jersey, 437 U.S. 6I7, 624 (1978); Raymond Motor Transportation, Inc. v. Rice, 434 U.S. 429, 44I-42 (1978); Hunt v. Washington Apple Advertising Commission, 432 U.S. 333, 352-54 (1977); Great Atlantic \& Pacific Tea Co. v. Cottrell, 424 U.S. 366, 371-72 (1976); Pike v. Bruce Church, Inc., 397 U.S. 137, 142 (1970).

${ }^{4}$ City of Philadelphia v. New Jersey, 437 U.S. 617, 621-23 (1978); Raymond Motor Transportation Co. v. Rice, 434 U.S. 429, 442-43 (1978).

${ }^{5}$ See, e.g., Moorman Manufacturing Co. v. Blair, 437 U.S. 267 (1978) (taxation); Exxon Corp. v. Governor of Maryland, 437 U.S. 117 (1978) (regulation).

${ }^{6} 99$ S. Ct. 1727 (1979).

${ }^{7}$ Okla. Stat. Ann. tit. 29 (West 1974).

${ }^{8}$ Id. at $\$ 4-116$. Persons acquiring and transporting minnows for their own use and children under sixteen selling minnows in the counties of their residence were exempt from these licensing requirements under specified conditions, as were retailers selhing lawfully acquired minnows. Ibid.
}

${ }^{9} I d$. at $\$ 4-115(\mathrm{~B})$. $\quad$ 10 Id. at $\$ 4-115(\mathrm{~B})(1),(2)$. 
sale of large quantities of "natural" (as distinguished from hatcherybred) minnows procured from Oklahoma waters. It did not impose any limitation on the disposition of hatchery-bred minnows, or on the procurement or sale of natural minnows within Oklahoma, or on the out-of-state transportation of natural minnows for purposes other than sale. Anyone convicted of violating these provisions was subject to a fine ranging from $\$ 100$ to $\$ 200 .^{11}$

William Hughes, a licensed minnow dealer of thirty years' standing under the laws of Texas, carried on a regular commercial minnow business near Wichita Falls, Texas, not far from the Oklahoma border. In the spring of 1976 , Hughes purchased for $\$ 350$ a load of natural minnows from an Oklahoma minnow dealer licensed as such under Oklahoma's Wildlife Conservation Code. On his way back to Wichita Falls with the load of minnows in his vehicle, Hughes was arrested by an Oklahoma Game Ranger. He was charged with "Unlawfully Transporting for Sale Outside of the State of Oklahoma Minnows Which Were Seined or Procured within the Waters of Olklahoma"12 in violation of the Conservation Code. The parties submitted the evidence to the trial court upon stipulated facts; the court found Hughes guilty as charged and fined him $\$ 200$.

On appeal, Hughes's sole assignment of error was that Oklahoma's ban on the exportation of minnows violated the Commerce Clause. He relied on the Supreme Court's decision in Foster-Fountain Packing Co. v. Haydel, ${ }^{13}$ which struck down a Louisiana statute forbidding the shipment beyond the State of shrimp taken in Louisiana waters until the heads and shells had been removed. Because the statute permitted the out-of-state exportation of shrimp after their heads and shells had been removed (as well as the exportation of the heads and shells themselves), the Court in Foster-Fountain determined that the statute's "purpose is not to retain the shrimp for the use of the people of Louisiana; it is to favor the canning of the meat and the manufacture of bran in Louisiana." 14 It concluded that the law's effect was "directly," i.e., impermissibly, "to obstruct and burden interstate commerce." 15 In so holding, the Court had

${ }^{11}$ Id. at $\$ \$ 4-115(\mathrm{D}) ; 4-116(\mathrm{E})$.

${ }^{12}$ Hughes v. State, 572 P.2d 573, 574 (Okla. Crim. App. 1977).

${ }^{13} 278$ U.S. 1 (1928).

${ }^{14}$ Id. at 13.

15 Ibid. 
to distinguish its earlier decision in Geer $v$. Connecticut, ${ }^{16}$ which sustained over Commerce Clause objections a Connecticut statute forbidding the transportation outside the State of game birds lawfully killed within the State. The ground of distinction was that Connecticut had prevented the game from becoming an article of interstate commerce by requiring it to be retained for consumption or use in the State, whereas Louisiana allowed "its shrimp to be taken and all the products thereof to be shipped and sold in interstate commerce," thereby "releas[ing] its hold" on the shrimp and putting "an end to the trust upon which the State is deemed to own or control the shrimp for the benefit of its people."17

In Hughes, the Oklahoma Court of Criminal Appeals found Geer and its progeny rather than Foster-Fountain controlling. It reasoned: ${ }^{18}$

The United States Supreme Court has held on numerous occasions that the wild animals and fish within a state's borders are, so far as capable of ownership, owned by the state in its sovereign capacity for the common benefit of all its people. Because of such ownership, and in the exercise of its police power, the state may regulate and control the taking, subsequent use and property rights that may be acquired therein.... Oklahoma law does not prohibit commercial minnow hatcheries within her borders from selling stock minnows to anyone, resident or nonresident, and minnows purchased therefrom may be freely exported. However, the law served to protect against the depletion of minnows in Oklahoma's natural streams through commercial exportation. No person is allowed to export natural minnows for sale outside of Oklahoma. Such a prohibition is not repugnant to the commerce clause.

\section{B. THE SUPREME COURT'S OPINION}

The Supreme Court reversed and held that the Oklahoma law violated the Commerce Clause. ${ }^{19}$ Repudiating its decision in Geer $v$. Connecticut, the Court determined that Oklahoma's statutory scheme must be evaluated under the same criteria governing the validity of state regulation of other natural resources, and that, under these criteria, Oklahoma's law could not withstand constitutional scrutiny. Oklahoma never suggested and the Court never

${ }^{16} 161$ U.S. $519(1896)$
${ }^{17} 278$ U.S. at 13.
18572 P.2d at 575.

19 99 S. Ct. 1727 (1979). 
considered that Congress had, in fact, consented to the statute by making it unlawful for any person knowingly "to transport . . . in interstate or foreign commerce, any black bass and other fish, if such ... transportation is contrary to the law of the State ... from which such black bass or other fish is transported." ${ }^{20}$ Indeed, a similar provision may be read as granting congressional consent to the result in Geer as well. ${ }^{21}$ Thus, Hughes may well have been wrongly decided in light of Congress' broad power to consent to state laws that would, in the absence of such consent, impose an impermissible burden on interstate commerce..$^{22}$ In any event, Hughes retains its significance for purposes of the present inquiry as the most recent expression of the Court's views regarding the negative implications of the Commerce Clause.

1. The overruling of Geer $v$. Connecticut. The state court's reliance on Geer as a basis for sustaining Oklahoma's ban on the transportation of natural minnows for out-of-state sale was fully understandable. Geer had, after all, upheld over Commerce Clause objections a prohibition against the transportation beyond the State of game birds lawfully killed within it. Once the Supreme Court agreed to hear Hughes's appeal, however, it was apparent that a defense predicated on Geer would face rough going.

The Court's analysis in Geer was rooted in its understanding of "the earliest traditions [of] the right to reduce animals ferae naturae to possession," ${ }^{23}$ which it gleaned from a reading of Athenian, ${ }^{24}$ Roman, ${ }^{25}$ Salic, ${ }^{26}$ feudal, ${ }^{27}$ and English common law. ${ }^{28}$ The Court had reasoned that wild game within a State, until reduced to possession, belonged to the people, who "owned" the game collectively for the common benefit of all $;^{29}$ that the State, as representative of its citizens, was invested with the authority to exercise the power

${ }^{20} 16$ U.S.C. $\$ 852$ (1976); cf. United States v. Howard, 352 U.S. 212 (1957). I am indebted to Professor William Cohen of the Stanford Law School for bringing this point to my attention.

${ }^{21}$ See 18 U.S.C. $\$ 43$ (1976).

${ }^{22}$ Prudential Insurance Co. v. Benjamin, 328 U.S. 408, 434-36 (1946); In re Rahrer, 140 U.S. 545 (1891); see Southern Pacific Co. v. Arizona, 325 U.S. 761, 769 (1945).

${ }^{23} 161$ U.S. at 522.

21 lbid.

251 . at $522-23$.

${ }^{20} \mathrm{Id}$. at $523-25$.
27 Ibid.

${ }^{28} I d$. at $526-28$.

29 Id. at 529. 
that was derived from this "common ownership" "as a trust for the benefit of the people"; $; 0$ that this power could be exercised not only to control the taking of game within the State but also to determine the nature of the property rights acquired in any game so taken; ${ }^{31}$ that the power therefore could be employed "to keep the property, if the sovereign so chooses, always within its jurisdiction for every purpose"; ${ }^{32}$ and, that: ${ }^{33}$

The power of the State to control the killing of and ownership in game being admitted, the commerce in game, which the state law permitted, was necessarily only internal commerce, since the restriction that it should not become the subject of external commerce went along with the grant and was part of it.

The Court in Geer proffered a second ground for its determination that Connecticut's embargo on the exportation of game did not offend the Commerce Clause. The statute represented an appropriate exercise of the State's police power derived from "the duty of the State to preserve for its people a valuable food supply." 34 The Court declared that the existence of this power was "equally conclusive" 35 of the outcome of the case as was the existence of state authority "derived from the common ownership of game and the trust for the benefit of its people which the State exercises in relation thereto." ${ }^{36}$ From this one might conclude that the "police power" rationale was independent of the "common ownership" rationale. Yet in the next breath the Court inextricably linked the two theories in observing that the State's police power to protect its people against adulteration of food carried with it "the existence of a like power to preserve a food supply which belongs in common to all the people of the State which can only become the subject of ownership in a qualified way, and which can never be the object of commerce except with the consent of the State and subject to the conditions which it may deem best to impose for the public good." 37

Whether Geer was predicated on one or two theories, its rationale (in either configuration) had been discredited by subsequent Su-

$\begin{array}{ll}{ }^{30} \mathrm{Ibid} . & { }^{34} \mathrm{Id} . \text { at } 534 . \\ { }^{31} \mathrm{Id} . \text { at } 530 . & { }^{35} \mathrm{Ibid} . \\ { }^{32} \mathrm{Ibid} . & { }^{36} \mathrm{Ibid} . \\ { }^{33} \mathrm{Id} . \text { at } 532 . & { }^{37} \mathrm{Id} . \text { at } 535 .\end{array}$


preme Court cases. The proposition that the State "owned" wild game within its borders for the common benefit of its citizens had been undermined by a series of decisions explicitly or implicitly rejecting such a contention. The Court had sustained the exercise of the federal treaty-making power over migratory birds in the face of a State's claim that this interfered with the State's ownership and control of wild animals within its boundaries, and it had remarked in passing that " $t]$ o put the claim of the State upon title is to lean upon a slender reed." 38 It had invalidated a prohibition on the exportation of shrimp taken within state waters until their heads and shells had been removed, dismissing arguments advanced by the State on the basis of its alleged ownership of the shrimp. ${ }^{39}$ It had struck down a state tax and regulatory scheme that discriminated against out-of-state commercial shrimp fishermen, disparaging the "ownership theory" as a legal fiction that stood as a proxy for other values the State might legitimately pursue, but not by discriminatory means. ${ }^{40}$ And, most recently, the Court had repudiated Geer's reasoning by making short shrift of the argument that a State's purported ownership of fish swimming in its territorial waters empowered it to forbid nonresident federal licensees from fishing there: ${ }^{41}$

A State does not stand in the same position as the owner of a private game preserve and it is pure fantasy to talk of "owning" wild fish, birds, or animals. Neither the States nor the Federal Government, any more than a hopeful fisherman or hunter, has title to these creatures until they are reduced to possession by skillful capture.... The "ownership" language of cases such as those cited by appellant must be understood as no more than a 19th-century legal fiction expressing "the importance to its people that a State have power to preserve and regulate the exploitation of an important resource." ... Under modern analysis, the question is simply whether the State has exercised its police power in conformity with the federal laws and Constitution.

Indeed, under the weight of these precedents, the State in Hugbes

${ }^{39}$ Missouri v. Holland, 252 U.S. 416, 434 (1920).

${ }^{39}$ Foster-Fountain Packing Co. v. Haydel, 278 U.S. 1, 11-13 (1928). See text supra, at notes 13-17.

${ }^{10}$ Toomer v. Witsell, 334 U.S. 385, 339-406 (1948).

${ }^{41}$ Douglas v. Seacoast Products, Inc., 431 U.S. 265, 284-85 (1977) (citations omitted). 
was forced to concede that "State 'ownership' may no longer be acceptable as a descriptive term of valid state interests in wildlife."42

Nor had the proposition that the States possessed the power (and, indeed, the duty) to conserve for their own citizens a valuable local food supply weathered the ravages of subsequent case law. The Court had held that States lacked the power to prohibit or limit the exportation of natural gas in the face of claims advanced by the States that they possessed " $[t]$ he right to conserve, or . . reserve, the resources of the State for the use of the inhabitants of the State, present and future." 43 The Court reasoned in these cases that whatever police power the States might have to conserve natural resources located within their borders, this power could not be exercised to limit the shipment or sale of privately owned resources in interstate commerce merely because they were needed by in-state consumers. ${ }^{44}$ Geer and its progeny were distinguished on the ground that they involved resources deemed to be owned by the State ${ }^{45}$-a proposition whose erosion was continuing apace with the dismantling of the broadly conceived conservation rationale. Moreover, as if events were conspiring to augur the impending demise of Geer, the Court had recently been provided with an opportunity to match its unkind remarks about Geer's ownership rationale with similarly critical comments about its conservation rationale. In holding that a State lacked power under the Commerce Clause to forbid the transportation of waste from other States into privately owned landfills within the State, the Court cited favorably its "decisions holding that a State may not accord its own inhabitants a preferred right of access over consumers in other States to natural resources located within its borders." 40

In Hughes, the Court was faced with the first case "in modern times to present facts essentially on all fours with Geer."47 Having traced the deterioration of Geer's analytical underpinnings, the Court had no qualms about administering the coup de grâce: "We

\footnotetext{
${ }^{42}$ Brief for Appellee, p. 6.

${ }^{43}$ West v. Kansas Natural Gas Co., 221 U.S. 229, 250 (1911); Pennsylvania v. West Virginia, 262 U.S. 553, 598-99 (1923).

44 West, 221 U.S. at 255; Pennsylvania, 262 U.S. at 599.

${ }^{45}$ West, 221 U.S. at 253-54. The majority opinion in Pennsylvania, 262 U.S. 553, did not allude to Geer, although Justice Holmes relied upon it in dissent. Id. at 601 .

${ }_{46}$ City of Philadelphia v. New Jersey, 437 U.S. 617, 627 (1978).

4799 S. Ct. at 1736.
} 
now conclude that challenges under the Commerce Clause to state regulations of wild animals should be considered according to the same general rule applied to state regulations of other natural resources, and therefore expressly overrule Geer." 48

2. The Court's opinion on the merits. Once it had discarded the "common ownership" and local conservation rationales underlying Geer, the Court was compelled to draw upon other principles of adjudication to resolve the controversy before it. Here the Court turned to a formulation of the criteria governing the constitutionality of state regulations affecting interstate commerce that has become fanuiliar reading to students of the Court's recent Commerce Clause opinions: ${ }^{49}$

Where the statute regulates evenhandedly to effectuate a legitimate local public interest, and its effects on interstate commerce are only incidental, it will be upheld unless the burden imposed on such commerce is clearly excessive in relation to the putative local benefits. . . . If a legitimate local purpose is found, then the question becomes one of degree. And the extent of the burden that will be tolerated will of course depend on the nature of the local interest involved, and on whether it could be promoted as well with a lesser impact on interstate activities.

Under these standards, the Court easily concluded that Oklahoma's statutory scheme failed to pass constitutional muster. Rather than regulating "evenhandedly," the law discriminated on its face against interstate commerce by blocking the flow of such commerce in natural ninnows at the State's borders. ${ }^{50}$ After suggesting that discrimination of this nature might give rise to "a virtually per se rule of invalidity," "si the Court nevertheless proceeded to

\section{${ }^{48}$ Ibid.}

49 Pike v. Bruce Church, Inc., 397 U.S. 137, 142 (1970) (citations omitted), quoted in Hughes, $99 \mathrm{~S}$. Ct. at 1734.

${ }^{50}$ See text supra, at notes 7-11. The flow was not blocked entirely; a tricklethree dozen or less natural minnows-could be exported from the State with impunity. Ibid.

51 Hughes, $99 \mathrm{~S}$. Ct. at 1737. The Court did not actually use the quoted phrase in Hughes, but it had employed the phrase in practically the identical context in City of Philadelphia v. New Jersey, 437 U.S. 617, 624 (1978): "where simple economic protectionism is effected by state legislation a virtually per se rule of invalidity has been erected. . . The clearest example of such legislation is a law that overtly blocks the flow of interstate commerce at a State's borders." The Court in Hughes explicitly referred to this passage from City of Pbiladelphia. 99 S. Ct. at 1737. 
evaluate the justification offered by the State for the discrimination but only under "the strictest scrutiny of any purported legitimate local purpose and of the absence of nondiscriminatory alternatives." "52

The "legitimate local purpose" advanced by Ollahoma in defense of the statute was its function as a "conservation measure."53 The Court acknowledged that the State's interest in preserving the ecological balance in its waters by restricting the removal of large numbers of minnows might well qualify as a legitimate local purpose. ${ }^{54}$ Indeed, the Court was willing to characterize such interests as "similar to the States' interests in protecting the health and safety of their citizens," considerable deference. ${ }^{56}$ But the question under the rubric articulated by the Court was one of degree, and whether the burden imposed by the State on interstate commerce was constitutionally tolerable would turn not only on the local interest involved but also on the availability of less burdensome means for achieving the same ends. The Court was firm in its conviction that the Oklahoma law failed on this score. The State had "chosen to 'conserve' its minnows in the way that most overtly discriminates against interstate commerce ... even though nondiscriminatory alternatives would seem likely to fulfill the State's purported legitimate local purpose more effectively." 57 Thus Oklahoma had, with a commercially insignificant exception, flatly proscribed the exportation of natural minnows for out-of-state sale, even though it might have pursued its objectives as well by restricting the number of minnows licensed dealers could take from state waters or by limiting the way in which such minnows might be disposed of in the State. ${ }^{58}$ While the Commerce Clause does not require the States to fine tune their legislation to minimize any conceivable impact it might have on interstate commerce, Oklahoma's effort to conserve its minnows reflected, at best, an unjustifiable indifference to such impact.

The State attempted to defend the means by which it had chosen

\footnotetext{
52 99, S. Ct. at 1737.

54 99 S. Ct. at 1737.

${ }^{53}$ Brief for Appellee, p. 2.

55 Ibid.

${ }^{56}$ Pike v. Bruce Church, Inc., 397 U.S. 137, 143 (1970).

5799 S. Ct. at 1737.

${ }^{58} \mathrm{Ibid}$; see text supra, at notes 7-11.
} 
to implement its legislative ends by contending that the statutory scheme embodied a closer fit between means and ends than might appear at first blush. Oklahoma argued that the ban on commercial exportation was the most effective means to maintain the desired ecological balance. The prohibition on transportation for out-ofstate sale, it was claimed, would assure that minnows seined and sold in Oklahoma would be "returned to Oklahoma waters in the form of bait," a procedure that served to "accommodate the recreational fisherman, while preserving the habitat and balance of aquatic wildlife provided by nature." 59 The Court dismissed this suggestion in a footnote. ${ }^{60}$ It observed that this theory, which the State was advancing for the first time on appeal, was predicated on factual assumptions that were unsupported by the record, and it characterized the argument as a "post-boc rationalization."61 The State's "bare assertion" 62 was wholly inadequate to overcome the presumptive invalidity of a facially discriminatory statute.

Mr. Justice Rehnquist dissented from the Court's decision in an opinion joined by the Chief Justice. Mr. Justice Rehnquist had no quarrel with the Court's abandonment of the "common ownership" doctrine of Geer. He would, however, have sustained the Oklahoma statute relying on the principles underlying Geer's "alternative basis"-"that a State, in the exercise of its police power, could act to preserve for its people a valuable food supply, even though interstate commerce was remotely and indirectly affected."63 Apart from the technical dispute over the independent significance of the Geer Court's alternative rationale, ${ }^{64}$ the crux of the disagreement between the majority and dissenting opinions was the weight each

${ }^{13}$ Brief for Appellee, p. 3.

on 99 S. Ct. at 1737 n.20.

B1 Ibid.

"5 Mr. Justice Rehnquist was of the view that the Geer Court's "police power" rationale was independent of its "common ownership" rationale. In light of his views regarding the scope of this police power, see $99 \mathrm{~S}$. Ct. at $1739-40$ and text infra, at note 65 , he saw no reason to overrule Geer. The majority, on the other hand, relying on the Geer Courr's failure to distinguish clearly between the premises underlying the two rationales, see text supra, at note 37 , believed that the "police power" rationale was simply a corollary of the "common ownership" rationale. $99 \mathrm{~S}$. Ct. at 1732 n.6. The majority also believed, however, that the "alternative basis" of Geer (as quoted supra, in the text above and at note 34), even if viewed independently, had failed to survive subsequent Snpreme Court decisions. See 99 S. Ct. at 1732 n.6 and text supra, at notes $43-46$. 
gave the State's interest in conservation and the view each held of what constitutes discrimination against interstate commerce. Mr. Justice Rehnquist, unlike the majority, would have permitted the State's "special interest" in preserving wildlife to prevail over Commerce Clause objections unless it represented "a naked attempt to discriminate against out-of-state enterprises in favor of in-state business unrelated to any purpose of conservation." this view, he found no discrimination in the Olklahoma scheme because the proscription on exportation applied to residents and nonresidents alike, did not protect residents from out-of-state competition, and was not employed as a means of inducing nonresident minnow exporters to shift their business operations into the regulating State. For the majority, by contrast, the fact that the state regulation substantially obstructed the flow of interstate commerce was in itself sufficient to condemn the regulation- or at least render it highly suspect-regardless of whether the obstruction had a differential economic impact on in-state and out-of-state interests.

Mr. Justice Rehnquist carried his dispute with the majority one step further by asserting, in light of the fact that hatchery-bred minnows were freely available for exportation, that the record did not support a determination that interstate commerce in minnows had been blocked by the Oklahoma legislation. In substance, $\mathrm{Mr}$. Justice Rehnquist was willing to sustain the statute failing proof by Hughes that the purchase of hatchery-bred rather than natural minnows would have been less desirable, more costly, or otherwise burdensome to his business operations. Mr. Justice Rehnquist would thus have stood the majority's analysis on its head: while the Court, having found discrimination on the face of a statute, would impose upon the State the burden of demonstrating the absence of less discriminatory means for accomplishing the same ends, he would impose upon a person subject to a discriminatory statute the burden of demonstrating the absence of equally efficient alternatives to avoid its impact.

Viewing the Court's decision in Hugbes in isolation, one would

${ }^{65} 99 \mathrm{~S}$. Ct. at 1740 . The "Commerce Clause objections" referred to in the text are those based on the negative implications of the Clause unimplemented by congressional legislation. Mr. Justice Rehnquist recognized that state regulations for the protection of wildlife would have to yield under other standards, to conflicting federal statutes and treaties as well as to the strictures of the Fourteenth Amendment. lbid. 
be hard pressed to conclude that it represented a case of much significance. It merely abandoned some quaint and antiquated doctrine about state "ownership" of wild animals to bring the law governing state regulation of such creatures into conformity with modern thinking about the constraints imposed by the Commerce Clause on state regulation of other matters. There are, however, at least two aspects of the Hughes decision that warrant further consideration. First, Hughes is the most recent of a series of Supreme Court opinions dealing with the limitations that the Commerce Clause imposes on state regulation, and its import may be more fully appreciated when viewed against the background of the Court's contemporary doctrine in this area. Second, Hughes is a case about state control over natural resources, a subject whose importance needs no emphasis in an era preoccupied with energy and the environment.

\section{Commerce Clause Restraints on State Regulation: General Principles}

It is a commonplace of modern Commerce Clause analysis that the Court, in delineating the implied limitations that the Clause imposes on state legislation, is engaged in a delicate balancing of state and national interests. ${ }^{66}$ The critical analytical problem, therefore, is to determine how the accommodation between competing demands of national economic unity and legitimate state policy is reached. The Court's recent Commerce Clause opinions-of which Hughes is the latest-suggest that the balancing process is being undertaken in a more consistent fashion than in the past.

It was in 1970 that the Court first articulated the formulation of Commerce Clause principles to which it has returned with remarkable regularity ever since. In Pike v. Bruce Cburch, Inc., ${ }^{67}$ an Arizona official had issued an order prohibiting a company from transporting Arizona-grown cantaloupes to California because they had not been packed according to the requirements of an Arizona statute. The company had been conducting its packing operations in Cali-

\footnotetext{
"6 This contemporary understanding has been shaped not only by scholarly commentary, see Dowling, Interstate Commerce and State Power, 27 VA. L. Rev. 1, 21-28 (1940); Dowling, Interstate Conmerce and State Power-Revised Version, 47 Colum. L. Rev. 547, 550-552 (1947); Freund, Umpiring the Federal System, 54 Colum. L. Rev. 561 (1954); but by judicial opinions as well. See, e.g., Southern Pacific Co. v. Arizona, 325 U.S. 761, 770-71 (1945).
}

${ }^{67} 397$ U.S. 137 (1970). 
fornia, and it was stipulated that "the practical effect of the [state official's] order would be to compel the company to build packing facilities in ... Arizona." ${ }^{68}$ Recognizing that the order "affected" and "burdened" interstate commerce, and that the critical question was whether it did so unconstitutionally, the Court unanimously declared: ${ }^{69}$

Although the criteria for determining validity of state statutes affecting interstate commerce have been variously stated, the general rule that emerges can be phrased as follows: Where the statute regulates evenhandedly to effectuate a legitimate local public interest, and its effects on interstate commerce are only incidental, it will be upheld unless the burden imposed on such commerce is clearly excessive in relation to the putative local benefits. If a legitimate local purpose is found, then the question becomes one of degree. And the extent of the burden that will be tolerated will of course depend on the nature of the local interest involved, and on whether it could be promoted as well with a lesser impact on interstate activities. Occasionally the Court has candidly undertaken a balancing approach in resolving these issues, but more frequently it has spoken in terms of "direct" and "indirect" effects and burdens.

Under these standards, the Arizona statute at issue failed to survive constitutional scrutiny. The State's interest in "promot[ing] and preserv [ing] the reputation of Arizona growers by prohibiting deceptive packaging"70 carried insufficient weight to offset the nation's interest in unfettered interstate commerce.

As Professor Kurland has observed, Pike was just "[a]n oldfashioned Commerce Clause case" whose outcome was predictable, and the fact that it even elicited an opinion from the Court may well have been "testimony to the advocate's skills of appellant's counsel and little more." 71 Nevertheless, the doctrinal formulation enunciated in Pike was repeated in Great Atlantic \& Pacific Tea Co. v. Cottrell, ${ }^{72}$ which invalidated a Mississippi regulation banning

\footnotetext{
${ }^{68} I d$. at 140.

${ }^{69} \mathrm{Id}$. at 142. (Citations omitted.)

70 Id. at 143.

${ }^{71}$ Kurland, Enter the Burger Court: The Constitutional Business of the Stpreme Court, O.T. 1969, 1970 Supreme Court Review 1, 79-80 (1970). The editors of the Harvard Law Review did not deem the case worthy of comment in their Supreme Court Note for that year. Note, The Supreme Court, 1969 Term, 84 Harv. L. Rev. 32 (1970).
}

72424 U.S. 366, 371-72 (1976). 
the sale in Mississippi of milk from other States unless such other States accepted Mississippi milk on a reciprocal basis. The Pike formulation was cited in Hunt v. Wasbington State Apple Advertising Commission, ${ }^{73}$ which struck down a North Carolina statute requiring that apples marketed within the State in closed containers be graded only according to the applicable United States standard. It was quoted in Raymond Motor Transportation, Inc. v. Rice, ${ }^{74}$ holding unconstitutional Wisconsin regulations governing the length and configuration of trucks permitted to travel on highways in the State. It was reiterated in City of Pbiladelpbia v. New Jersey, ${ }^{75}$ disapproving a New Jersey law prohibiting the importation into the State of most solid or liquid waste collected outside its territorial limits. And finally, it was set forth in Hughes v. Oklaboma, where it was characterized as "[ $\mathrm{t}$ ] oday's principle."76 Indeed, with one exception, ${ }^{77}$ this catalogue embraces every significant ${ }^{78}$ opinion handed down by the Court over the last decade in which it has applied the substantive standards ${ }^{79}$ derived from the negative implications of the Commerce Clause to state regulation of interstate commerce. $^{80}$

73432 U.S. 333, 350, 353 (1977).

744 U.S. $429,441-42$ (1978).

${ }^{77}$ Exxon Corp. v. Governor of Maryland, 437 U.S. 117 (1978) (upholding over Commerce Clause objections a state statute forbidding producers or refiners of petroleum products from owning or operating retail gasoline stations in the state).

${ }^{74}$ I do not regard either Ray v. Atlantic Richfield Co., 435 U.S. 151 (1978), or Allenberg Cotton Co. v. Pittman, 419 U.S. 20 (1974), as "significant." Ray was a case dealing primarily with federal preemption of state law, see note 80 infra, and its treatment of the Commerce Clause claim was cursory. See 435 U.S. at 179-80. Allenberg Cotton involved the question whether a foreign corporation could be denied the right to sue in the State's courts because it had not qualified to do business there. The essential question was whether the corporation had sufficient contacts with the State to justify the qualification requirement, and the Court concluded that it did not. 419 U.S. at 33. Hence the refusal by the State to honor and enforce the contracts of an exclusively interstate business was deemed to violate the Commerce Clause. Id. at 34.

${ }^{70}$ In Hughes v. Alexandria Scrap Corp., 426 U.S. 794 (1976), the Court upheld a Maryland statutory scheme involving the payment to scrap processors by the States of cash bounties that favored in-state processors in alleged violation of the Commerce Clause. The Court held that the negative implications of the Commerce Clause were not applicable to the scheme at issue, although the Court did advert to the $P$ ike formulation in passing. Id. at 804-05. The case is discussed in text infra, at notes $144-49$.

80 The generalization in the text is not directed to two categories of cases which sometimes share common doctrinal themes with, but are in significant respects distinct from, the cases that are the subject of this article. First, the Court's opinions 
Before we consider what this development may signify, it may be useful as a preliminary matter to establish what it does not signify. First, it does not signify any substantive departure from the standards the Court has employed in the past in adjudicating Commerce Clause attacks on state regulation. Indeed, every one of the elements of the Pike test can be found explicitly or implicitly in many of the Court's prior opinions. ${ }^{81}$ Nor does adoption of the Pike testif adoption it be-promise greater precision in judgment or predictability of outcomes than in the past. The Commerce Clause balance will continue to be struck substantially as it has always been struck

addressing Commerce Clause limitations on state taxation may refer to the regulatory cases and the principles underlying them. See, e.g., Boston Stock Exchange v. State Tax Commission, 429 U.S. 318, 328-29, 335-36 (1977). Nevertheless, the controversies in this area frequently involve issues that are unique to the exercise of state tax power, see generally Hellerstein \& Helierstein, State and Local. Taxation, Cases and Materials 237-335, 391-454, 662-92 (4th ed. 1978), and generally cannot be fruitfully assimilated with the regulatory cases for purposes of analysis. It might be noted, however, that the Court has enunciated and reiterated a set of decisional principles governing the validity of state taxes on interstate commerce, a development that may loosely be seen as parallel to the development in the regulatory context. See $i d$. at 249,287 ; notes $1 \& 2$ supra; Blumstein, Some Intersections of the Negative Commerce Clause and the New Federalism: The Case of Discriminatory State Income Tax Treatment of Out-of-State Tax-excmpt Bonds, 31 Vand. L. Rev. 473 (1978); Hellerstein, State Taxation and the Supreme Court: Toward a More Unified Approacb to Constitutional Adjadication?, 75 Mich. L. Rev. 1426, 1441-52 (1977).

Second, the Court's opinions confronting questions of federal preemption of state law may draw on principles one ordinarily associates with the negative implications of the Commerce Clause, especially in cases in which those implications might have provided an alternative ground of decision. Sce Douglas $v$. Seacost Products, Inc., 431 U.S. 265, 285-87 (1977); Morrison, Tl.e Right to Fish for Seacoast Products: Gibbons v. Odgen Resurrected, 1977 Suprene Court ReviEw 239, 246-50 (1977); Note, Pre-emption as a Preferential Ground: $A$ New Canon of Construction, 12 Stan. L. Rev. 208, 219-21 (1959). Nevertheless, federal preemption cases usually involve considerations quite different from those derived solely from the negative implications of the Commerce Clause, and the discrete analytical framework within which preemption cases are adjudicated reflects these differences. Jones v. Rath Packing Co., 430 U.S. 519, 525-26 (1977). To be sure, if a preemption claim is rejected, the Court must in many instances squarely confront a claim based entircly on the implied restraints of the Commerce Clausc. See, e.g., City of Philadelphia v. New Jersey, 437 U.S. 617, 620-21 n.4 (1978). Bur if the Commerce Clause claim has in substance been disposed of through the resolution of the preemption question, it is likely to be given short shrift. See, e.g., Ray v. Atlantic Richfield Co., 435 U.S. 151, 179-80 (1978).

${ }^{81} \mathrm{Sec}$ e.g., Huron Portland Cement Co. v. City of Detroit, 362 U.S. 440, 443 (1960). ("Evenhanded local regulation to effectuate a legitimate local interest is valid unless ... unduly burdensome on ... interstate commerce"); Dean Milk Co. v. City of Madison, 340 U.S. 349, 354 (1951) (State cannot exercise "its unquestioned power to protect the health and safety of its people" in a discriminatory fashion "if reasonable nondiscriminatory alternatives, adequate to conserve legitimate local interests, are available"). 
by conscientious judges, by a careful weighing of the competing state and national interests in light of all the facts and circumstances of the case. ${ }^{82}$ Whether a consumer protection law limiting the grading of apples marketed in the State to "U.S. grades" satisfies the standards of $P i k e^{83}$ can scarcely tell us whether a highway safety law forbidding the operation in the State of trucks longer than fifty-five feet will do so. ${ }^{84}$ At most, the fluid criteria of Pike provide a framework for Commerce Clause analysis; they provide no litmus test of constitutionality. ${ }^{85}$

Still, it would be wrong to dismiss the Court's repeated invocation of the Pike formulation as merely an accident of opinion drafting or a prefunctory nod to doctrinal consistency. The Court's recent Commerce Clause opinions stress common themes that are reflected in the Pike formulation and the patterns of emphasis are worthy of note. First, the Court has been more forthright than in the past in accepting its own role of making the "delicate adjustment of the conflicting state and federal claims"86 required by the Commerce Clause. The open acknowledgment that it is balancing interests ${ }^{87}$ and the explicit weighing of the competing considerations $^{88}$ tend to illuminate the Commerce Clause calculus. As a result,

${ }^{82}$ Frankfurter, The Commerce Clause under Marshald, Taney and Waite 21-22, 33-34 (1964 ed.).

${ }^{83}$ Hunt, 432 U.S. 333.

${ }^{84}$ Raymond Motor, 434 U.S. 429.

\& Indeed, a textual analysis of the Pike formulation raises many more questions than it answers. Thus the formulation does not tell us when a statute regulates "evenhandedly," see note 102 infra and accompanying text, nor what constitutes a "Iegitimate local public interest," nor what kinds of effects on interstate commerce are "incidental." It does not tell us whether a statute's failure to meet any one of these tests necessarily means that it is unconstitutional, or whether one must continue to balance state and national interests, but with altered presumptions. See text infra, at notes 103-06. And it does not tell us what respect is to be accorded to various local interests nor how to determine whether an alternative scheme might pronote such interests "as well." See text infra, at notes 89-93 and 107-10. This is not meant to suggest, however, that the Pike formulation was designed to answer any of these questions. See generally Blasi, Constitutional Limitations on the Power of States to Regulate the Movement of Goods in Interstate Commerce 18-21, paper presented at the Conference on the Judicial Role in Economic Integration, Bellagio, Italy, July 17-21, 1979 (to be published).

${ }^{80}$ H.P. Hood \& Sons, Inc. v. DuMond, 336 U.S. 525, 553 (1949) (Black, J., dissenting), quoted in Cottrell, 424 U.S. at 371, and Raymond Motor, 434 U.S. at 440.

${ }^{\text {s7 Pike, }} 397$ U.S. at 142; Cottrell, 424 U.S. at 371-72; Hunt, 432 U.S. at 350, 353; Raymond Motor, 434 U.S. at 441-43; City of Pbiladelpbia, 437 U.S. at 624; Hughes, 99 S. Ct. at $1734,1736$.

${ }^{49}$ Pike, 397 U.S. at 145-46; Cottrell, 424 U.S. at 375-76; Hunt, 432 U.S. at 351-54; Raymond Motor, 434 U.S. at 444-46; Hughes, 99 S. Ct. at 1737-78. 
we may speak with more confidence about the narrow principle for which a particular case stands as well as the Court's view of the relative importance of various state interests. For example, it seems fair to conclude from Pike itself that a State's legitimate interest in preserving the reputation of a local industry is less substantial than the nation's interest in permitting business operations to be performed at their most efficient locations. ${ }^{89}$ Moreover, we know that the State's interest asserted in Pike is less substantial in the Court's eyes than the State's interest in the safety, health, or employment of its citizens. ${ }^{90}$ We have also been told in recent opinions that the State's interest in safety ranks high in the Court's constellation of values, ${ }^{91}$ that highway safety may enjoy an especially exalted status, ${ }^{92}$ and that the State's interests in conservation and protection of wild animals are "similar" to its interest in health and safety. ${ }^{93}$

Second, the Court's apparent conviction that the Pike formulation embodies the controlling criteria for adjudicating contemporary Commerce Clause controversies is evidenced by its willingness to repudiate doctrine and precedent inconsistent with the Pike standards. In Raymond Motor, the Court emphatically rejected Wisconsin's contention, based on earlier cases, ${ }^{94}$ that "the general rule of Pike is not applicable to a State's regnlation of motor vehicles in the promotion of safety" merce Clause is ended without a weighing of the asserted safety purpose against the degree of interference with interstate commerce." 96 In City of Pbiladelpbia, the Court rejected New Jersey's contention, based on earlier cases, ${ }^{97}$ that innately harmful articles such as wastes were "not legitimate subjects of trade and commerce"98 and therefore fall outside the pale of Commerce Clause

\footnotetext{
${ }^{89}$ Pike, 397 U.S. at $143,145-46$.

${ }^{90} \mathrm{Id}$. at $143,146$.

${ }^{91}$ Raymond Motor, 434 U.S. at 443.

${ }^{92}$ Ibid.

${ }^{93}$ Hughes, 99 S. Ct. at 1737.

${ }^{94}$ E.g., South Carolina State Highway Department v. Barnwell Bros., 303 U.S. 177 (1938).

${ }^{95}$ Raymond Motor, 434 U.S. at 442.

${ }^{96} I d$. at 443 . This was not the first time the Court had rejected such a claim. See Bibb v. Navajo Freight Lines, 359 U.S. 520, 528-29 (1959). As to the application of "the general rule of $P i k e$ " in the highway safety context, see note 118 infra.

${ }^{97}$ E.g., Bowman v. Chicago \& Northwestern R. Co., 125 U.S. 465 (1888).

${ }^{98} \mathrm{Id}$. at 489, quoted in City of Pbiladelphia, 437 U.S. at 622.
} 
protection and the general principles set forth in Pike. "All objects of interstate trade merit Commerce Clause protection; none is excluded by definition at the outset." ${ }^{\text {999 }}$ And in Hughes, the Court overruled Geer and thus brought Commerce Clause challenges to state regulation of wild animals under "the same general rule applied to state regulatio[n] of other natural resources," 100 namely, the rule of $P i k e .^{101}$

Third, the Court has focused considerable attention on two substantive aspects of the Pike formulation in resolving the disputes before it. The first is one that has always been a critical factor in Commerce Clause analysis: whether the state law, on its face or in effect, regulates "evenhandedly." Although there is nothing in its opinions to suggest that the Court is drawing brighter lines than in the past between "evenhanded" and discriminatory legislation, ${ }^{102}$ the Court has made it clear that when, in its judgment, a state law fails to accord "evenhanded" treatment to interests protected by the Commerce Clause, the consequences are pratically inevitable. Thus when a state law "overtly blocks the flow of interstate commerce at a State's borders," 103 "a virtually per se rule of invalidity has been erected." ${ }^{104}$ At the very least, once a determination is made that a state law discriminates against interstate commerce, the State is under a heavy burden to demonstrate that the local interest allegedly justifying the discrimination could not be effectuated by less discriminatory means. ${ }^{105}$ If, on the other hand, the Court determines that a statute regulates "evenhandedly," its chances of surviving constitutional scrutiny are greatly enhanced. ${ }^{106}$

The other substantive aspect of the Pike formulation which has played a key role in recent Commerce Clause cases is the Court's searching evaluation of the alternatives available to the State to achieve its purported objectives when the means the State has actu-

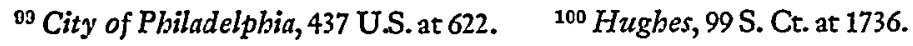

101 Id. at 1734.

${ }^{102}$ Compare Exxon Corp. v. Governor of Maryland, 437 U.S. 117 (1978), with Hunt, 432 U.S. 333; see note 77 supra; Blumstein, note 80 supra, at 501-08; Note, The Supreme Court, 1977 Term, 92 Harv. L. Rev. 57, 66-75 (1978).

${ }^{103}$ City of Pbiladelpbia, 437 U.S. at 624.

104 Ibid; see also Hughes, 99 S. Ct. at 1737.

${ }^{105}$ Hunt, 432 U.S. at 353; Hughes, 99 S. Ct. at 1736.

${ }^{103}$ See text supra, at note 70. 
ally chosen are found to be burdensome or discriminatory. The Court noted in Cottrell that Mississippi had "the obvious alternative of applying its own standards of inspection to shipments of milk from a nonreciprocating State,"107 instead of completely barring such shipments. It noted in Hunt that North Carolina could effectuate its goal of protecting consumers from fraud or confusion "by permitting out-of-state growers to utilize state grades only if they also marked their shipments with the applicable U.S.D.A. label,"108 instead of insisting on the exclusive use of the latter. And it indicated in Hughes that Oklahoma might have achieved its conservation objectives by limiting the numbers of minnows that could be taken from state waters by licensed dealers rather than through its choice of a method "that most overtly discriminates against interstate commerce."109 Although the consideration of less burdensome alternatives is not novel Commerce Clause jurisprudence, ${ }^{110}$ the Court seems to be weighing this factor in the balance with greater care and consistency than before. ${ }^{111}$

There are yet further indicia not directly identifiable with the Pike formulation which also suggest that the Court's reiteration of a single test embodying its approach to Commerce Clause questions is not mere happenstance. Four of the six decisions involing the Pike standard were unanimous; ${ }^{112}$ in the other two, only the Chief Justice and Mr. Justice Rehnquist dissented. ${ }^{113}$ Moreover, the Court's opinions were written by four Justices who span the Court's ideological spectrum. ${ }^{114}$ One may reasonably conclude that whatever is going on is going on with a substantial degree of consensus.

As I indicated earlier, it is important to resist the temptation to

${ }^{107}$ Cottrell, 424 U.S. at 377.

108 Hunt, 432 U.S. at 354.
${ }^{109}$ Hughes, 99 S. Ct. at 1737.

${ }^{110}$ See note 81 supra.

11 See Note, State Environmental Protection Legislation and the Comnerce Clause, 87 Harv. L. Rev. 1762, 1781 (1974).

${ }_{112}$ Pike, 397 U.S. 137; Cottrell, 424 U.S. 366 (Stevens, J., did not participate); Hunt, 432 U.S. 333 (Rehnquist, J., did not participate); Raymond Motor, 434 U.S. 429 (Blackmun, J., joined in the opinion of the Court, but wrote a concurring opinion joined by the Chief Justice and Justices Brennan and Rehnquist, see note 118 infra; Stevens, J., did not participate).

${ }^{113}$ City of Pbiladelpbia, 437 U.S. 617, Hughes, 99 S. Ct. 1727.

${ }^{114}$ Chief Justice Burger (Hunt); Mr. Justice Stewart (Pike and City of Pbiladelpbia); Mr. Justice Brennan (Cottrell and Hughes), and Mr. Justice Powell (Raymond Motor). 
see more in the Court's opimions than is actually there. We must not forget that the Court has written Commerce Clause opinions in recent years that do not conform precisely to the suggested pattern; $;{ }^{115}$ that, in any event, the pattern embodies little that is new from a doctrinal standpoint; ${ }^{110}$ and, more generally, that the Court in deciding Commerce Clause cases today is not doing anything fundamentally different from what it has always done in resolving these controversies. ${ }^{11 \tau}$ Furthermore, even assuming that the Pike formulation embraces the criteria the Court has presently adopted for adjudicating Commerce Clause cases, the formulation is sufficiently imprecise that the result of its application to particular disputes remains highly uncertain. ${ }^{118}$ Nevertheless, while there may be less in these opinions than meets the eye, they do attest to the Court's achievement of an increased measure of doctrinal consistency in an important area of constitutional law.

\section{I1I. Commerce Clause Restraints on State Control of Natural Resources}

If a new war is going to be fought over the control and exploitation of the nation's natural resources, ${ }^{119}$ the Supreme Court will surely be an important battleground. Although such conflicts are nothing new to the nation or the Court, ${ }^{120}$ they have acquired special significance in an age of anxiety over shortages of energy and other natural resources. The problem, of course, is not limited to controversies in which the States themselves are the face-to-face

\footnotetext{
${ }^{115}$ See notes 77-79 supra.
}

${ }^{116}$ See note 81 supra.

${ }^{117}$ See text supra, at notes 66 and 82.

${ }^{118}$ Indeed, Mr. Justice Blackmun's concurring opinion in Raymond Motor, 434 U.S. at 48-51, which three other Justices joined, supports the view that the Court's reliance on the Pike standard in different contexts does not mean that the Court is striking a similar balance in each case. Mr. Justice Blackmun opined that "if safety justifications are not illusory, the Court will not second-guess legislative judgment about their importance in comparison with related burdens on interstate commerce." Id. at 449 . Of course, the general point seems implicit in the Pike formulation itself.

${ }^{110}$ See, e.g." "The Second War between the States," Business WEek 92-114 (May 17, 1976); but see Pack, Frostbelt and Sunbelt: Convergence over Time, 4 INTERGOVERNMENTAL PERSPECTIVE 8-15 (Fall 1978).

${ }^{120}$ Sec, e.g., Pennsylvania v. West Virginia, 262 U.S. 553 (1923); Kansas v. Colorado, 206 U.S.76 (1907). 
combatants, although we have recently witnessed our share of these. ${ }^{121}$ More frequently the conflict arises, as in Hughes v. Oklaboma, in the form of a dispute between a private party seeking to use a resource and a State that has imposed limitations on its use.

Whatever questions there may once have been about the nature of the restraints that the Commerce Clause imposes on state control of natural resources, Hugbes and other Supreme Court decisions of recent vintage ${ }^{122}$ have enunciated a number of propositions that, for the moment at least, can be regarded as settled. Some of these propositions represent a simple application of the Pike formulation to natural resource regulation; others relate to specific issues arising in the natural resource context. The apparent harmony among members of the Court regarding the proper approach to many problems it has confronted in connection with natural resource regulation has not, however, led to a resolution of all of them.

\section{A. STATE CONTROL OF PRIVATELY OWNED NATURAL RESOURCES}

The implied restraints imposed by the Commerce Clause on state control of privately owned natural resources are in principle identical to the Commerce Clause restraints imposed on other aspects of state regulation. A statute regulating privately owned natural resources must do so "evenhandedly." It may not discriminate against interstate commerce by preventing the shipment of the resource outside the State, ${ }^{123}$ by restricting access to the resource from outside the State, ${ }^{124}$ or by providing that in-state demands for the resource be accorded preference over out-of-state demands. ${ }^{125}$ The needs of local consumers for privately owned natural resources located within a State, even if they constitute legitimate local public interests, do not justify discriminatory legislation. ${ }^{126}$ Although the Court could conceivably be persuaded to sustain such legislation in

\footnotetext{
${ }^{121}$ Maryland v. Louisiana, No. 83 Orig., Motion for leave to file bill of complaint granted, 99 S. Ct. 2876 (1979); City of Philadelphia v. New Jersey, 437 U.S. 617 (1978).

${ }^{122}$ City of Pbiladelpbia, 437 U.S. 617; Hicklin v. Orbeck, 437 U.S. 518 (1978); Baldwin v. Fish \& Game Commission, 436 U.S. 371 (1978); Douglas v. Seacoast Products, Inc., 431 U.S. 265 (1977).

${ }^{123}$ West v. Kansas Natural Gas Co., 221 U.S. 229 (1911).

${ }^{124}$ City of Pbiladelpbia, 437 U.S. 617.

${ }^{125}$ Pennsylvania v. West Virginia, 262 U.S. 553 (1923).

${ }^{126}$ Foster-Fountain Packing Co. v. Haydel, 278 U.S. 1, 10 (1928).
} 
the absence of nondiscriminatory alternatives capable of achieving the same objective, the burden of persuasion on the State in this context seems well nigh insuperable. ${ }^{127}$

Evenhanded regulation of privately owned natural resources, on the other hand, is quite likely to withstand Commerce Clause scrutiny. The States have a legitimate local interest in conserving natural resources located within their borders, ${ }^{128}$ and it is an interest that ranks high in the Court's hierarchy of legitimate local purposes. ${ }^{129}$ Since the burden that evenhanded regulation imposes on interstate commerce will be tolerated unless it is "clearly excessive in relation to the putative local benefits," 130 such regulation of natural resources will generally be sustained even if its effect is to increase the price ${ }^{131}$ or decrease the supply ${ }^{132}$ of the resource. ${ }^{133}$ The possibility that the regulation may be economically inefficient ordinarily gives rise to no substantial constitutional objection. ${ }^{134}$ The Constitution did not enact Adam Smith's Wealth of Nations any more than it enacted Herbert Spencer's Social Statics. ${ }^{135}$

\section{B. STATE CONTROL OF STATE-OWNED NATURAL RESOURCES}

When the focus shifts from privately owned natural resources to those that are owned by the State, the Commerce Clause analysis becomes considerably more problematic. Indeed, in holding in City

${ }^{127}$ Hughes, 99 S. Ct. at 1736-38; City of Pbiladelpbia, 437 U.S. at 626-27; see text supra at notes 103-05.

${ }^{128}$ Cities Service Gas Co. v. Peerless Oil \& Gas Co., 340 U.S. 179 (1950).

${ }^{129}$ Hughes, 99 S. Ct. at 1737. ${ }^{130}$ Pike, 397 U.S. at 142.

131 Cities Service Gas Co., 340 U.S. 179.

132 Parker v. Brown, 317 U.S. 341, 367 (1943).

${ }^{133}$ The results of a number of earlier cases are consistent with the statement in the text, although the reasoning underlying them does not reflect modern Commerce Clause analysis. For example, Commerce Clause objections to state statutes regulating the production of natural gas were routinely dismissed on the ground that production was a local activity distinct from interstate commerce. See, e.g., Champlin Refining Co. v. Corporation Commission, 286 U.S. 210, 235 (1932). In these cases, the Court gave more serious attention to the claim that the statutes violated the resource owners' economic due process rights, but these claims too were generally rejected. See, e.g., ibid; see also Summers, The Moderm Theory and Practical Application of Statutes for the Conservation of Oil and Gas, 13 Tulane L. Rev. I (1938); Note, The Constitution and State Control of Natural Resources, 64 HaRv. L. Rev. 642, 644 (1951).

${ }^{134}$ Exxon Corp. v. Governor of Maryland, 437 U.S. 117, 124-29 (1978); see Tribe, Amierican Constitutional Law, 25 (1979 Supp.).

${ }^{135}$ Lochner v. New York, 198 U.S. 45, 75 (1905) (Holmes, J., dissenting). 
of Pbiladelpbia that New Jersey could not bar the importation of out-of-state waste into privately owned landfills in the State, the Court explicitly declined to express any "opinion about New Jersey's power, consistent with the Commerce Clause, to restrict to state residents access to state-owned resources." ${ }^{30}$ There is little direct guidance from the Court regarding the limitations that the Clause imposes on state control of such resources, and, as indicated below, what guidance there is does not all point in the same direction.

It must be stressed fron the outset that the references to the State's ownership interest in a natural resource as an organizational principle should not be taken to suggest that the State's ownership interest is necessarily a critical or, in some instances, even a helpful concept for purposes of analyzing the limitations that the Commerce Clause imposes on state control of natural resources. As will be seen, the nature of the State's ownership interest in a natural resource is generally only one of several factors to be considered in the Commerce Clause calculus. Still, it does seem useful, at least as a starting point of analysis, to distinguish between two types of situations involving state control of natural resources that are not privately owned. First, there are cases in which the State possesses interests in natural resources which, if they were held by a private person, would be regarded as amounting to substantial ownership, as, for example, a State's interest in trees growing on state lands. Second, there are cases in which the State's interest, even if characterized in terms associated with ownership, would ordinarily be regarded as significantly more limited, as, for example, a State's interest in water running in intrastate streams.

If a State enjoys conventional ownership rights in a natural resource, two (sometimes overlapping) considerations emerge that seem to limit the application of the Commerce Clause principles established with regard to state control of privately owned natural resources. First, there is the notion that the Commerce Clause does not require a State to spend state funds, provide state services, or otherwise distribute its resources-whether natural or man-madeto in-state residents and businesses and out-of-state residents and businesses on a nondiscriminatory basis. ${ }^{137}$ Second, when a State 
is acting as a purchaser or seller in-as distinguished from a regulator of-the market, there is authority to suggest that it is not restrained by the negative implications of the Commerce Clause. ${ }^{138}$ Both of these considerations and their impact on the Commerce Clause require further elaboration.

The proposition that the State may, at least in some circumstances, favor resident individuals and businesses in the distribution of state resources without violating the Constitution would seem to be a logical corollary of the basic assumptions underlying our federal system. "If," to take an example from McCready v. Virginia, ${ }^{139}$ "Virginia had by law provided for the sale of its once vast public domain, and a division of the proceeds among its own people, no one, we venture to say, would contend that the citizens of other States had a constitutional right to the enjoyment of this privilege of Virginia citizenship." ${ }^{140}$ Nor, it may be suggested, would anyone venture to say that such action would be proscribed by the negative implications of the Commerce Clause. Whatever limitations the Constitution in general and the Commerce Clause in particular impose on the ability of the States to discriminate in favor of local interests and to prevent nonresidents from becoming residents, ${ }^{141}$ it is difficult to imagine these limitations extending so far as to bar the States from making any distinctions between in-state and out-ofstate interests in distributing state resources without destroying the essential fabric of our constitutional plan. Although the principle that a State may favor its own in the distribution of state resources without running afoul of the Commerce Clause has arguably been accorded implicit sanction in the few cases that have presented the issue, ${ }^{142}$ the Court has formally maintained a posture of neutrality regarding a State's "power, consistent with the Commerce Clause ... to spend state funds solely on behalf of state residents and businesses."143

${ }^{139}$ See text infra, at notes $144-49$.

13994 U.S. 391 (1876).

${ }^{140}$ Id. at 395-96.

${ }^{141}$ And these are substantial. See text infra, at notes 159-76.

${ }^{142}$ Hughes v. Alexandria Scrap Corp., 426 U.S. 794 (1976), discussed in text infra, at notes 144-49; American Yearbook Co. v. Askew, 409 U.S. 904, aff'g, 339 F. Supp. 719 (M.D. Fla. 1972) (sustaining over Commerce Clause objections statute requiring tbat all public printing be done in the State).

${ }^{143}$ City of Plitadelpbia, 437 U.S. at 627 n.6. 
The Court has been explicit, however, in approving the doctrine that the Commerce Clause imposes no restraints on the State when it enters the marketplace as a purchaser, and the State is therefore free under the Clause to favor in-state residents and businesses when spending state funds in that capacity. In Hughes v. Alexandria Scrap Corp. ${ }^{144}$ the Court upheld a Maryland statute designed to encourage the disposal of abandoned automobiles through payments of cash bounties to scrap processors. The Court found that the statute did not violate the Commerce Clause, even though the distribtuion of the bounties favored in-state interests. ${ }^{145}$ The Court recognized that it was confronted with a "situation ... w without precedent in this Court."146 It distinguished previous cases in which a State had sought to "interfer[e] with the natural functioning of the interstate market either through prohibition or through burdensome regulation"147 from the case before it in which the State had simply "entered into the market itself" "as a purchaser, in effect, of a potential article of interstate commerce." ${ }^{148}$ And it concluded that "[n]othing in the purposes animating the Commerce Clause prohibits a State ... from participating in the market and exercising the right to favor its own citizens over others."149

Whatever may be the limits of these two related but analytically distinct principles, ${ }^{150}$ their logic suggests that the Commerce Clause

144426 U.S. 794 (1976).

${ }^{145}$ To be eligible for the bounty, scrap processors were required in some instances to provide documentation of title to the junk automobiles. The documentation requirements for out-of-state processors were more burdensome than those imposed on processors with plants in Maryland.

146426 U.S. at 807.

${ }^{147} I d$. at 806.

${ }^{148} \mathrm{Id}$. at $806,808$.

${ }^{149} \mathrm{Id}$. at 810 . Most other courts that have considered Commerce Clause challenges to resident preferences in state purchasing or contracting have likewise rejected them, sometimes resting their conclusions on the perceived distinction between a State's governmental functions, which were thought to be subject to the negative strictures of the Commerce Clause, and its proprietary functions, which were not. See, e.g., American Yearbook Co, v. Askew, 339 F. Supp. 719, 725 (M.D. Fla. 1971), aff'd, 409 U.S. 904 (1972); Schrey v. Allison Steel Manufacturing Co., 75 Ariz. 282 (1953); Tribune Printing \& Binding Co. v. Barnes, 7 N.D. 591, 597 (1898); but see Garden State Dairies, Inc. v. Sills, 46 N.J. 349 (1966), noted in 80 Harv. L. Rev. 1357 (1967); see generally Comment, In-State Preferences in Public Contracting: States' Rights Versus Economic Sectionalism, 49 U. CoLo. L. Rev. 205, 216-22 (1978). In other cases, the fact that the benefits were financed largely by the resident's own tax dollars was thought to be important. See, e.g., Reeves, Inc. v. Kelley, 586 F.2d 1230, 1233 (8th Cir. 1978), discussed infra, at notes 177-86.

${ }^{150}$ And there are definite limits to them. In addition to those discussed below, 
would not prevent a State from distributing or selling state-owned natural resources to in-state residents or businesses on a preferential basis. And this is a sound conclusion. While one may be troubled by some of its implications ${ }^{151}$ and dissatisfied with the analysis by which some courts have reached it, ${ }^{152}$ the opposite conclusion would be even more disturbing. To preclude the States from preferring instate interests in the distribution of state natural resources would deprive the States of an important attribute of their separate existence as independent political units in the federal system. ${ }^{153}$ The denial to the States of the power to provide for their residents as such would undermine the relationship between the States and their residents. Moreover, forbidding the States from preferring their own in the distribution of their resources would introduce into the federal system an unsettling asymmetry between the respective obligations the resident and nonresident owe to the State and the benefits they enjoy there. ${ }^{154}$ Whether it would be good national policy to deny the States the power to favor in-state interests in this context and whether Congress in pursuit of such policy

see text infra, at notes $159-75$, it is worth noting that the Court has dismissed arguments that the States may discriminate against interstate commerce in their regulation of state highways because of the State's ownership interests in the roads. Buck v. Kuykendall, 267 U.S. 307 (1925); see also South Carolina State Highway Department v. Barnwell Bros., 303 U.S. 177, 187-89 (1938); cf. West v. Kansas Natural Gas Co., 221 U.S. 229, 261-62 (1911); see generally Linde Constitutional Rights in the Public Sector: Justice Douglas on Liberty in the Welfare State, 40 WAsH L. REv. 10, 49-67 (1965). Although the State is plainly acting as a regulator in this context, if there were no limits to the theory that the State could favor in-state interests in distributing state-owned resources, one might contend that the State is simply providing a state-owned resource, a highway, to in-state interests on a preferential basis. The Court's unwillingness to brook State discrimination against instrumentalities of interstate commerce regardless of any asserted ownership interest by the State in their highways simply underscores the point made earlier in the text that state ownership, standing by itself, is no talisman of Commerce Clause analysis.

${ }^{151}$ See, e.g., Hughes v. Alexandria Scrap Corp., 426 U.S. 795, 817-18, 828-29 (1976) (Brennan, J., dissenting); Linde, note 150 supra; Note, State Purchasing Activity Excluded from Commerce Clause Review, 18 B.C. IND. \& CoM. L. Rev. 893 (1977).

${ }^{152}$ The governmental-proprietary distinction, see note 149 supra, has been a darling of academic criticism. See, e.g., Davis, Administrative Law Treatise $\$ 25.07$ (1958); Prosser, HandBook of THE LAW OF Torts $\$ 131$, at 979, 982 (4th ed. 1971); see generally Wells \& Hellerstein, The Govermmental-Proprietary Distinction in Constitutional Law, 66 VA. L. Rev. (April 1980).

${ }^{153}$ Cf. National League of Cities v. Usery, 426 U.S. 833 (1976).

${ }^{154}$ See Hellerstein, Some Reflections on the State Taxation of a Nonresident's Personal Income, 72 Mich. L. Rev. 1309, 1318-19 (1974). 
could legislate to that end ${ }^{155}$ are, of course, different questions. The only question here is whether the Commerce Clause by its own force withdraws this power from the States. While the Commerce Clause may have been designed to create a national common market, it would take more than a "great silence"156 to sever the special relationship between a State and its in-state residents and businesses. ${ }^{167}$

It is important to recognize, however, that the suggested conclusion, even if correct, is a narrow one. It does not tell us whether the disposition of state-owned natural resources on a preferential basis to in-state residents and businesses would pass muster under other contitutional provisions, although it seems likely that it would. ${ }^{158}$ Nor does it indicate the force of two limiting principles, whose impact is substantial. First, whatever distinctions the State may make between in-state and out-of-state interests with regard to the allocation of the State's natural resources, it is plain that it has only minimal powers to deny anyone the right to become a resident of the State or to accord him less than the full panoply of privileges it accords its long-time residents. ${ }^{159}$ If a New Yorker ${ }^{155}$ See National League of Cities, 426 U.S. 833.
${ }^{156}$ H.P. Hood \& Sons v. DuMond, 336 U.S. 525, 535 (1949).
${ }^{157}$ Cf. Toomer v. Witsell, 334 U.S. 385,408 (1948) (Frankfurter, J., concurring).
${ }^{158}$ Alexandria Scrap Corp, 426 U.S. 794 (in-state preference in distribution of cash subsidies no violation of Equal Protection Clause); Starns v. Malkerson, 401 U.S. 985 (1971), aff'g, 326 F. Supp. 234 (D. Minn. 1970), and Sturgis v. Washington, 414 U.S. 1057, aff'g, 368 F. Supp. 38 (W.D. Wash. 1973) (resident preference in tuition rates at state universities no violation of "right to travel" or Equal Protection Clause); see also Vlandis v. Kline, 412 U.S. 441, 452-53 (1973); cf. Heim v. McCall, 239 U.S. 175 (1915), and Crane v. New York, 239 U.S. 195 (1915) (resident preference in public employment no violation of Equal Protection or Due Process Clauses). Although the Court has expressed some doubt about the continuing vitality of Heimn and Crane, see Hicklin v. Orbeck, 437 U.S. 518, 531 n.15 (1978), it would appear that they are still good authority for the proposition that a State may favor its own residents over nonresidents with regard to state employment, even if the State may not favor those of its own residents who are American citizens over aliens, whether resident or nonresident. Sugarman v. Dougall, 413 U.S. 634 (1973); C.D.R. Enterprises, Ltd. v. Board of Educ., 412 F. Supp. 1164 (E.D.N.Y. 1976), aff'd sub nom. Lefkowitz v. C.D.R. Enterprises, Lid., 429 U.S. 1031 (1977); see Note, The Supreme Court, 1977 Term, 92 Harv. L. Rev. 57, 83 n.47 (1978). But of. Ambach v. Norwick, 99 S. Ct. 1589 (1979); Foley v. Connelie, 435 U.S. 291 (1978). See generally Rosberg, Protecting the Right of Free Movement of Persons in the United States, 87-93, 100-02, paper presented at the Conference on the Judicial Role in Economic Integration, Bellagio, Italy, July $17-21,1979$ (to be published).

${ }^{159}$ See Memorial Hospital v. Maricopa County, 415 U.S. 250 (1974); Dunn v. Blumstein, 405 U.S. 330 (1972); Shapiro v. Thompson, 394 U.S. 618 (1969); but see Sosna v. Iowa, 419 U.S. 393 (1975); see generally Rosberg, note 158 supra, at $50-68$. 
wants to enjoy the benefits Alaska may be bestowing upon its residents as a result of its ownership of vast amounts of oil, there is little more than the price of transportation to prevent him from doing so. Second, the power the States may have to discriminate in favor of their in-state residents and businesses in the distribution of stateowned natural resources does not permit the States to attach conditions to the use or disposition of the resource that might independently burden interstate commerce or some other constitutionally protected interest. While Alaska may be able to sell its oil to residents at a preferred price, it may not, as the Court recently informed us in Hicklin v. Orbeck, ${ }^{160}$ compel "all businesses that benefit in some way from the economic ripple effect of Alaska's decision to develop its oil and gas resources to bias their employment practices in favor of the State's residents."161

In Hicklin, the Supreme Court struck down under the Privileges and Immunities Clause an Alaska statute requiring that residents be preferred over nonresidents with regard to "all employment which is a result of oil and gas leases, easements, leases or right-of-way permits for oil or gas pipeline purposes ... to which the state is a party." "182 One of the grounds on which Alaska sought to defend the statute was that it owned all of the oil and gas with respect to which the employment preferences were required, and that the Privileges and Immunities Clause was inapplicable to "decisions by the states as to how they would permit, if at all, the use and distribution of the natural resources which they own."163 The Court responded: ${ }^{164}$

We do not agree that the fact that a State owns a resource, of itself, completely removes a law concerning that resource from the prohibitions of the Clause. ... Rather than placing a statute completely beyond the Clause, a State's ownership of the property with which the statute is concerned is a factor -although often the crucial factor-to be considered in evaluating whether the statute's discrimination against noncitizens violates the Clause.

The State's ownership was not enough to justify the discrimination in Hicklin because Alaska had "little or no proprietary interest in

160437 U.S. 518 (1978).

161 Id. at 531.

${ }^{102}$ Alaska Stat. $\$ 38.40 .050$ (a) (1977), quoted at 437 U.S. 529.

${ }^{103}$ Brief for Appellee, p. 20 n.14, quoted at 437 U.S. 528.

164 437 U.S. at 528-29. 
much of the activity swept within the ambit of [the statute]"105 and "the connection of the State's oil and gas with much of the covered activity [was] sufficiently attenuated so that it cannot justifiably be the basis for requiring private employers to discriminate against nonresidents." 100

Hicklin was decided under the Privileges and Immunities Clause, which in some instances provides an alternative to the Commerce Clause as a basis for constitutional adjudication. ${ }^{\mathbf{1 6 7}}$ The analytical route by which a decision is reached under the two Clauses, however, is ordinarily quite different. ${ }^{168}$ Even so, the Court in Hicklin specifically relied on "the mutually reinforcing relationship"160 between the Privileges and Immunities and Commerce Clauses in an extensive dictum invoking precedents under the latter to bolster its conclusion under the former. The Court referred to its decisions establishing that the Commerce Clause forbade the States from attempting to preserve for their own residents the benefits of privately owned natural resources located within their borders. ${ }^{170}$ It went on to observe that in Foster-Fountain Packing Co. v. Haydel, ${ }^{171}$ involving Louisiana's prohibition on the out-of-state shipment of shrimp prior to local processing, the Court had limited the implications of the still vital doctrine of Geer-that Louisiana's purported ownership of the shrimp justified the State's discrimination in favor of in-state interests. The Court in Foster-Fountain had found that

165 Id. at 529.

186 lbid.

${ }^{167}$ Cf. Ward v. Maryland, 12 Wall. 418 (1870). Notwithstanding the occasional overlap, there are considerable differences in the scope of the two Clauses. The Privileges and Immunities Clause affords no protection to corporations, Paul v. Virginia, 8 Wall. 168 (1868), and thereby has no application to many enterprises engaged in interstate commerce. Moreover, even though a state law does not discriminate against nonresidents, so that no objection to it could plausibly be raised under the Privileges and Immunities Clause, it might still be offensive to the Commerce Clause. Cf. Bibb v. Navajo Freight Lines, Inc., 359 U.S. 520 (1959) (nondiscriminatory highway-safety regulation).

168 Compare, e.g., Pike, 397 U.S. 137, witb Hicklin, 437 U.S. 518. In cantrast to the Court's internal agreement over the governing decisional principles in the Commerce Clause context, there is continuing disagreement among members of the Court regarding the proper approach to Privileges and Immunities questions. Compare Hicklin, 437 U.S. 518, witb Baldwin v. Fish and Game Commission, 436 U.S. 371 (1978); see TRIBE, supra nate 134, at 34-40.

169437 U.S. at 531.

${ }^{170} \mathrm{Id}$. at 532, discussing West, 221 U.S. 229, and Pennsylvania, 262 U.S. 553; see text sipra, at notes $43-46$ and 123-25.

171278 U.S. 1 (1928). See text supra, at notes $13-17$. 
"by permitting its shrimp to be taken and all the products thereof to be shipped and sold in interstate commerce, the State necessarily releases its hold and, as to the shrimp so taken definitely terminates its control."172 Based on its reading of all these cases, the Court concluded that: ${ }^{173}$

the Commerce Clause circumscribes a State's ability to prefer its own citizens in the utilization of natural resources found within its borders, but destined for interstate commerce. Like Louisiana's shrimp in Foster Packing, Alaska's oil and gas here are bound for out-of-state consumption ... Although the fact that a state-owned resource is destined for interstate commerce does not, of itself, disable the State from preferring its own citizens in the utilization of the resource, it does inform analysis under the Privileges and Immunities Clause as to the permissibility of the discrimination the State visits upon nonresidents based on its ownership of the resource. ... [T] he breadth of the discrimination mandated by [the statute] goes far beyond the degree of resident bias Alaska's ownership of the oil and gas can justifiably support.

Although the Court in Hicklin was only incidentally concerned with the Commerce Clause, several inferences regarding its view of the restraints the Clause imposes on state control of state-owned natural resources may fairly be drawn from its remarks. The Court is apparently of the view that the Commerce Clause imposes some limits on a State's ability to prefer in-state residents and businesses in the utilization of state-owned natural resources destined for interstate commerce. Foster-Fountain, which the Court treated in the same breath as the "private ownership" cases, might have been dismissed as a case involving the "fiction" of state ownership in which the Court had enunciated a rule that was consistent with the reality of private control. But in Hicklin it was clear that Alaska owned the oil and gas as much as it is capable of owning anything. ${ }^{174}$ Yet the analogy the Court drew between Foster-Fountain and Hicklin leaves little doubt that it would strike down on Commerce Clause grounds restrictions on state-owned natural resources of the type Louisiana sought to impose on the commercial exploitation of its shrimp. Thus any ban or conditions on the private sale, use, or exportation of a state-owned natural resource favoring in-state in-

172278 U.S. at 13, quoted at 437 U.S. at 533.

173437 U.S. at 533.

${ }^{174}$ Id. at $528 \mathrm{n} .11$. 
terests would very likely be invalidated. On the other hand, the Court did allow that "the fact that a state-owned resource is destined for interstate commerce does not, of itself, disable the State from preferring its own citizens in the utilization of that resource." ${ }^{175}$ The Court thereby reinforced the central conclusion advanced above, namely, that the Commerce Clause does not forbid the States, at least under some conditions, from favoring in-state residents and businesses in the allocation of state-owned natural resources.

Finally, and perhaps as a useful reminder of the unsettled state of the law in this area, the most recent word from the Court bearing on these issues injects a distinct element of uncertainty with regard to its views. In Reeves, Inc. v. Kelley, ${ }^{176}$ the South Dakota Cement Commission, created by the state legislature to carry out the manufacture, distribution, and sale of cement as "works of public necessity and importance,"177 refused to sell cement to out-of-state customers in accordance with its policy of supplying all South Dakota customers first. The United States Court of Appeals for the Eighth Circuit, reversing the decision of the district court, held that the Commission's action did not violate the Commerce Clause. Relying principally on the Supreme Court's decision in Hugbes v. Alexandria Scrap Corp., the court observed that: ${ }^{178}$

South Dakota has not attempted to pass any regulation or prohibition on any private industry functioning in commerce. It has simply acted in a proprietary capacity as a seller of cement within the interstate cement market.

The court refused to attribute any significance to the fact that Maryland was a purchaser in Alexandria Scrap, whereas South Dakota was a seller in the case before it, on the reasonable premise that the holding in Alexandria Scrap was rooted in the distinction between the State's participation in and its regulation of the market, not in the distinction between inward- and outward-moving commerce. ${ }^{179}$ And it concluded: ${ }^{180}$

While a state is similar to private business when it participates in the market in a purely proprietary capacity, it is also some-

\footnotetext{
175437 U.S. at 533.

${ }^{176} 586$ F.2d 1230 (8th Cir. 1978).

${ }^{177} \mathrm{Id}$. at 1231.
}

${ }^{178} I d$. at 1232.

${ }^{179}$ Id. at 1233 n.4.

${ }^{180} I d$. at 1233 (citations omitted). 
what different. As a government providing a public service and utilizing the money and resources of its residents, it has a right and perhaps even an obligation to consider their common good and conserve their resources so long as it does not do so by attempting to regulate or control commerce among the states.... The factual background in these cases does not indicate that South Dakota has attempted to control channels of interstate commerce. Accordingly, we hold the commerce clause does not prohibit the State of South Dakota "from participating in the market and exercising the right to favor its own citizens over others." Hughes v. Alexandria Scrap Corp. Cf. American Yearbook Co. v. Askew.

The unsuccessful purchaser petitioned the Supreme Court for certiorari and, three weeks after its decision in Hughes v. Oklaboma, the Court issued the following order::

Petition for writ of certiorari granted, judgment vacated and case remanded to the Court of Appeals for further consideration in light of Hughes v. Oklaboma. ... ${ }^{181}$

The Court's reference to Hughes v. Oklaboma is puzzling. From a doctrinal standpoint, Hugbes did little more than extinguish what little life was left in the fiction of state ownership of wildlife located within its borders and thus brought the framework for adjudicating state regulation of such wildlife into line with the general principles of Pike and the privately owned natural resource cases. But South Dakota's ownership of the cement at issue in Reeves was not based on any fiction. It was like Alaska's gas and oil in Hicklin. Perhaps, as Hicklin suggests, there are Commerce Clause limits on what South Dakota may do with its cement. But unless Hughes v. Oklaboma in some mysterious way undermined Hughes v. Alexandria Scrap, it is difficult to see the precise bearing that a case dealing with a State's regulation of wildlife owned by nobody has on a case dealing with a State's sale of cement owned by the State.

There are, however, other plausible explanations of the Court's cryptic remand. First, the Court may not have been concerned about the precise bearing of Hughes $v$. Oklaboma on Reeves, Inc. $v$. Kelley. It might have been trying to make the more general point to the Court of Appeals that a State's alleged ownership of a resource-fictional or actual-is but one of many factors to be taken

191 99 S. Ct. 2155 (1979). 
into account in the Commerce Clause balance and that the court had accorded too much weight to the fact of state ownership. If this is what the Court is saying, however, it would seem on the facts presented to signal a retreat from the implications of Hugbes $v$. Alexandria Scrap Corp. Second, it is possible that the Court really perceives no constitutional distinction between the "private" and "public" ownership cases. One would, however, expect the Court to be more explicit in articulating its position on this matter, especially in light of its specific discussion of the issue in earlier cases. ${ }^{182}$ Third, it is possible that the Court viewed the South Dakota Cement Commission as more of a regulator of than a participant in the market, although the record below does not provide much support for this position. Finally, it is possible that the Court viewed the case as presenting difficult issues that were likely to arise only in rare instances. By remanding the case, the Court might have hoped to receive further illumination about the problem or, alternatively and perhaps preferably, to have it disappear. On remand, the Court of Appeals adhered to its earlier holding. ${ }^{183}$

\section{STATE CONTROL OF NATURAL RESOURCES IN WHICH OWNERSHIP INTERESTS ARE NOT CLEARLY ESTABLISHED}

The discussion in the preceding two subsections was addressed to cases of state control of natural resources in which ownership of the resource, whether private or public, was clearly established under conventional property-law concepts. There is, however, a third category of cases involving state control of natural resources such as wildlife, water, and air in which ownership interests, if they exist at all, are often not well established.

In Hughes $v$. Oklaboma the Court was dealing with wildlife, a natural resource that in its view was owned by no one. "[I]t is pure fantasy to talk of 'owning' wild fish, birds, or animals. Neither the

182 See text supra, at notes 136 and 162-73.

${ }^{183}$ Reeves, Inc. v. Kellev, 603 F.2d 736 (8th Cir. 1979). The court found Hughes v. Oklaboma distinguishable because South Dakota had not prevented privately owned articles of trade from being shipped in interstate commerce. "We conclude that [South Dakota's] action is more similar to Maryland's preference for its residents in its entry into the automobile scrap processing market, upheld in Hughes v. Alexandria Scrap Corp, than conduct at which the prohibitions of the Commerce Clause have historically been directed." Reeves sought Supreme Court review of the Court of Appeals' decision on remand, 48 L.W. 3310 (Nov. 6, 1979), and, at this writing, its petition for certiorari was awaiting Supreme Court action. 
States nor the Federal Government, any more than a hopeful fisherman or hunter, has title to these creatures until they are reduced to possession by skillful capture." 184 In thus repudiating the "19thcentury legal fiction" of state ownership, ${ }^{185}$ the Court concluded that "challenges under the Commerce Clause to state regulations of wild animals should be considered according to the same general rule applied to state regulations of other natural resources." 186 What the Court meant, of course, was the same general rule it had applied to state regulation of privately owned natural resources. Although one might have argued as an original proposition that the State should be accorded greater leeway in controlling unowned than privately owned natural resources, the Hughes opinion contains little evidence that a distinction between the two types of cases may properly be drawn. ${ }^{187}$ If, therefore, a determination is made that a claim of state ownership to a resource is a "fiction," it seems fair to infer from Hughes that state regulation of the resource must satisfy the criteria of Pike, and no special weight will be attributed to the absence of private ownership. Hence game birds, ${ }^{188}$ natural minnows, ${ }^{189}$ shrimp, ${ }^{100}$ and other free-roaming ${ }^{191}$ and freeswimming ${ }^{102}$ creatures, whose peculiar constitutional status has long

19499 S. Ct. at 1735-36, quoting Douglas, 431 U.S. at 284.

185 99 S. Ct. at 1736.

${ }^{187}$ Mr. Justice Rehnquist expressed the "hope" that some of the principles he thought were controlling may have survived the overruling of Geer, $99 \mathrm{~S}$. Ct. at 1379 (see text stpra, at notes 63-65), but his references to those statements in the Court's opinion acknowledging the power and interest of the States to protect and conserve wildlife within their borders provide scant basis for such optimism. The State's power to conserve natural resources located within their borders through evenhanded measures has been a consistent theme in the Court's opinions dealing with privately owned natural resources. See text supra, at notes 123-33. While the Court declared that the States' interests in conserving wildlife were "similar" to their interests in protecting the health and safety of their citizens, 99 S. Ct. 1737, it might well reach the same conclusion regarding the States' interests in conserving privately owned natural resources. See text supra, at notes 123-33.

${ }^{188}$ Geer, 161 U.S. 519; cf. Missouri v. Holland, 252 U.S. 416 (1920).

${ }^{189}$ Hughes, 99 S. Cr. 1727.

${ }^{100}$ Toomer v. Witsell, 334 U.S. 385 (1948); Foster-Fountain Packing, 278 U.S. 1.

${ }^{101}$ Cf. Baldwin v. Fish \& Game Commission, 436 U.S. 371 (1978); Kleppe v. New Mexico, 426 U.S. 529 (1976); Lacoste v. Louisiana Department of Conservation, 263 U.S. 545 (1924); Patsone v. Pennsylvania, 232 U.S. 138 (1914).

${ }^{102}$ Bayside Fish Flour Co. v. Gentry, 297 U.S. 722 (1936); Manchester v. Massachusetts, 139 U.S. 240 (1891); of. Douglas v. Seacost Products, Inc., 431 U.S. 265 (1977); Takahashi v. Fish \& Game Commission, 334 U.S. 410 (1948); Lawton v. Steele, 152 U.S. 133 (1894); see generally Morrison, note 80 supra, at 250-55. 
commanded the Court's attention, are now apparently to be treated substantially the same as privately owned natural resources for purposes of Commerce Clause adjudication. ${ }^{193}$

Once one leaves the area of wildlife, however, the terrain becomes less certain. Two cases handed down by the Court in the heyday of nineteenth-century legal fictions suggest some of the difficulties likely to be encountered in this context under contemporary Commerce Clause analysis. In McCready v. Virginia, ${ }^{194}$ a Maryland resident, who had planted oysters in Virginia's inland tidewaters, was convicted of violating a statute forbidding nonresidents from planting oysters in Virginia waters. Over McCready's objections that the prohibition violated the Privileges and Immunities and Commerce Clauses, the Court sustained the conviction. Dismissing the latter claim on the ground that production is not commerce ${ }^{195}$ the Court devoted its principal attention to the former.

It began with the "settled" doctrine that "each State owns the beds of all tide-waters within its jurisdiction ... [ [and] the tidewaters themselves."196 "For this purpose," the Court continued, "the State represents its people, and the ownership is that of the people in their united sovereignty." ${ }^{197}$ The Court therefore reasoned that the State: ${ }^{198}$

has the right to appropriate its tide-waters and their beds to be used by its people as a common for taking and cultivating fish. ... Such an appropriation is in effect nothing more than a regulation of the use by the people of their common property.

${ }^{193}$ This is not to suggest, however, that every state law that would pass constitutional muster as an evenhanded regulation of wildlife would likewise survive constitutional scrutiny as a regulation of privately owned resources. A law forbidding any hunting of certain animals might well be sustained as an evenhanded conservation measure; a law forbidding any production of oil from privately owned wells would raise more difficult constitutional issues. This may simply be another way of saying that the Court's decision in Hugbes has not divested the States of their traditional role as managers of wildlife located within their borders, so long as such management is undertaken on a nondiscriminatory basis.

19494 U.S. 391 (1876).

${ }^{195}$ Id. at 396-97. McCready also argued that the statute was preempted by federal laws "relating to the coast trade," $i d$. at 394 , but the Court did not explicitly address this contention. The Court's decision in Douglas, 431 U.S. 265 (1977), may be read as casting some doubt on the continuing validity of the Court's disposition of this issue in McCready. See Lewis \& Strand, Douglas v. Seacoast Products, Inc.: The Legal and Economic Consequences for the Maryland Oystery, $38 \mathrm{MD}$. L. Rev. 1, 8 (1978); see also note 80 supra.

19694 U.S. at 394.

${ }^{197}$ Ibid.

198 Id. at 395. 
In light of these principles, and the premise that the Privileges and Immunities Clause "extended only to such privileges and immunities as are 'in their nature fundamental; which belong of right to the citizens of all free governments," "199 the Court had no hesitation in concluding that Virginia had not denied a Maryland resident a "privilege" or "immunity" of citizenship by confining the use of Virginia's oyster beds to its own residents. "We think we may safely hold that the citizens of one State are not invested by this clause of the Constitution with any interest in the common property of the citizens of another State." ${ }^{200}$

From a doctrinal standpoint, $\mathrm{McCready}$ has unquestionably been eroded. Production may not be commerce, but its regulation by the State will be limited by the negative implications of the Commerce Clause if such production substantially affects commerce among the States. ${ }^{201}$ It may be that only "fundamental" rights are protected by the Privileges and Immunities Clause, ${ }^{202}$ but the Court today might strike down the Virginia statute under that Clause as an impermissibly pervasive discrimination against nonresidents to achieve whatever goals it may permissibly pursue as a consequence of its ownership of the resource. ${ }^{203}$ Moreover, the Court has repeatedly asserted that " $[t]$ he whole ownership theory, in fact, is now generally regarded as but a fiction expressive in legal shorthand of the importance to its people that a State have power to preserve and regulate the exploitation of an important resource."204 For some or all of these reasons, most observers have routinely concluded that McCready is "anachronistic," 205 subject to "significant doubts," ${ }^{200}$ and "a derelict on the sea of legal history."207

${ }^{199}$ Ibid., quoting Corfield v. Coryell, 6 Fed. Cas. 546 (Case No. 3,230) (C.C.E.D. Pa. 1825).

20094 U.S. at 395.

${ }^{201}$ Parker v. Brown, 317 U.S. 341, 359-68 (1943); cf. United States v. Darby, 312 U.S. 100 (1941); Philadelphia v. New Jersey, 437 U.S. 617, 621-23 (1978).

${ }^{202}$ See Baldwin v. Fish \& Game Commission, 436 U.S. 371 (1978).

${ }^{203}$ Hicklin, 437 U.S. 518.

${ }^{204}$ Toomer v. Witsell, 334 U.S. 385,402 (1948).

${ }^{205}$ Note, Domicile Preferences in Employment: The Case of Alaska Hire, 1978 Duke L.J. 1069, 1076 (1978).

${ }^{200}$ Nowak, Rotunda, \& Young, Handbook on Constrtutionat Law 278 (1978). ${ }^{207}$ Morrison, note 80 supra, at 252. Professor Morrison was referring generally to the "Corfield category of special interests," ibid., which was embodied in the holding of $M c$ Cready.Id. at 252 n.72. 
Perhaps so. But $\mathrm{McCready}$ may not be ready for last rites. The Commerce Clause ${ }^{208}$ would today impose some limits on the restrictions Virgima might place on the use of its tidelands. The central question, however, is whether those limits are the same as the restraints imposed on its control of wildlife or whether they are more akin to the limits imposed on its control of state-owned natural resources, which contemplate the possibility of some in-state preferences, without regard to the availability of nondiscriminatory alternatives. The discrediting of the "common ownership" doctrine does not necessarily resolve the issue. That doctrine has been maligned largely in cases involving the State's claim to ownership of wildlife which, as a practical matter, nobody owned. ${ }^{209}$ But tidelands are arguably analytically distinct from fish and birds. The States have an interest in their tidelands which, while distinguishable from A's fee interest in Blackacre, may nevertheless be characterized as a substantial one. ${ }^{210}$ Hence, even if the "common ownership" theory on which the State's claims were originally predicated has no place in contemporary Commerce Clause analysis-whether wildlife or tidelands are at issue-it does not necessarily follow that the consequences in each instance are the same. Exposure of the fiction of "common ownership" of game may lead to the conclusion that in reality it is owned by no one and that the Commerce Clause criteria governing privately owned natural resources should therefore apply. ${ }^{211}$ But exposing the fiction of "common ownership" of tidelands may reveal that in reality the State's ownership

${ }^{208}$ With regard to the Privileges and Immunities Clause, it is quite possible that the Court would reach a different conclusion in $\mathrm{McCready}$ today for the reason suggested above. See text supra, at note 203. Some support for the continuing vitality of the holding of $M c$ Cready, however, may be found in Baldwin v. Fish \& Game Commission, 436 U.S. 371, 383, 386 (1978) (sustaining Montana's elk-hunting license scheme which discriminated against nonresidents) and in parts of the following discussion.

${ }^{209}$ Hughes, 99 S. Ct. 1727, 1735-36 (minnows); Baldwin, 436 U.S. 371, at 385-86 (elk); Doutglas, 431 U.S. 265, at 284 (fish); Toomer, 334 U.S. 385, at 401-02 (shrimp); Missouri v. Holland, 252 U.S. 416, 434 (birds); $c f$. Manchester v. Massachusetts, 139 U.S. 240, at 265 (1891) (fish).

${ }^{210}$ See Note, The Public Trust in Tidal Areas: A Sometime Submerged Traditional Doctrine, 79 YaLE L.J. 762 (1970); the Submerged Lands Act, 43 U.S.C. $\$ \$ 1301-15$ (1976) (conveying to the States "title," "ownership," and "the right and power to manage, administer, lease, develop and use" the lands beneath the oceans and natural resources within state territorial jurisdiction); and Dottglas, 431 U.S. at $284-85$.

${ }^{211}$ See text supra, at notes 184-93. 
interest is significant, and that the appropriate analogy for Commerce Clause purposes would be to state mineral holdings or state forests rather than wildlife. There is considerable learning and controversy concerning the States' interest in the tidelands, ${ }^{212}$ and no claim to expertise is being made here. The point is only that tidelands may be different from wildlife with regard to the reality of state ownership and its recognition for Commerce Clause purposes. ${ }^{213}$

A second factor that might bear on the determination whether Virginia's oyster beds should be treated differently from unowned resources under the Commerce Clause is the extent to which the State itself had acted as a proprietor of the resource. If the States had expended large sums of money to develop, manage, and cultivate oyster beds located in state waters, one might regard the entire enterprise as a "statewide oyster 'farm" "214 subsidized by the State, to which access might reasonably be limited to in-state residents and businesses under the principle discussed in the preceding subsection.

While these factors could breathe some new life into McCready, there are countervailing considerations that should not be ignored. The general drift of Supreme Court doctrine in this area has been toward greater freedom in the interstate market, ${ }^{215}$ and, when the case is close, "free trade" interests are likely to prevail over the States' interests in providing for their own, which are easily portrayed as forces of "economic Ballkanization."216 Moreover, in dealing with the tidelands, the Court may feel it is dealing with a resource that is impressed with a national interest, ${ }^{217}$ and it thus might be particularly vigilant in protecting the resource from local economic prejudice. Finally, even if some concession to the States'

\footnotetext{
21:2 Sec, e.g., United States v. California, 332 U.S. 19 (1947), and sources cited therein; see also note 210 sipra.

${ }^{213}$ Whatever the impact the States' "ownership" of their tidelands under 43 U.S.C. $\$ \$ 1301-15$ (see note 210 supra) on the negative implications of the Commerce Clause, the Court made it clear in Douglas that such "ownership" did not permit them to limit the rights of federal licensees, who are nonresidents of the State, to fish in their waters. It has been suggested, however, that the statutory preemption in Douglas was "only the old negative implications of the Commerce Clause in a new guise." Morrison, note 80 supra, at 250; see note 195 supra.
}

${ }^{214}$ Lewis \& Strand, note 195 supra, at 13-14.

${ }^{215}$ See text supra, at notes 70-80.

${ }^{216}$ Hughes, 99 S. Ct. at 1731.

${ }^{217}$ See notes 210 and 212 supra. 
ownership interest in their tidelands is made, it must be kept in mind that the States are confined in their ability to translate this ownership interest in a resource into restrictions that would independently burden the Commerce Clause. ${ }^{218}$ Indeed, in Jobnzson $v$. Haydel, ${ }^{219}$ a companion case to Foster-Fountain, the Court invalidated Louisiana's attempt to impose, with respect to oysters it claimed to own, restrictions similar to those it had sought to impose on the interstate shipment of shrimp. Whatever limits Virginia may still be able to impose on access to its oyster beds under a refurbished version of $\mathrm{McCready}$, it surely may not impose any limitations on the disposition of oysters taken from those beds, beyond those limitations that are permissible as applied to a privately owned resource.

Like their interest in oyster beds located within their jurisdictions, the States' interest in water situated within their borders may be strong enough to raise questions regarding their power over the resource that cannot be disposed of merely by reference to cases involving wildlife. In Hudson County Water Co. v. McCarter, ${ }^{22 n}$ the Court upheld a New Jersey statute making it unlawful for anyone to export "the waters of any fresh water lake, pond, brook, creek, river or stream of this State into any other State, for use therein." 221 Over objections predicated on the Contract, Commerce, Due Process, Equal Protection, and Privileges and Immunities Clauses, the Court sustained an injunction against a water company under contract with the City of New York to prevent the company from carrying waters of a New Jersey river outside the State. Without deciding whether the State could prohibit the acquisition of large quantities of water from state streams in its capacity as "owner" of the bed of the stream and of all rights in the water not belonging to riparian proprietors, ${ }^{222}$ the Court preferred to rest its decision "upon a broader ground ... [that] is independent of the more or less attenuated residuum of title that the State may be said to possess." 223 In substance, the Court held that the State's "police power... . to protect the atmosphere, the water and the forests within its territory,"224 authorized it "to maintain

\footnotetext{
${ }^{218}$ See text supra, at notes 160-75. $\quad{ }^{222}$ Id. at 354 .

219278 U.S. 16 (1928).

${ }^{223} I d$. at 355 .

${ }^{220} 209$ U.S. 349 (1908).

224 Ibid.

221 Id. at 353 .
} 
the rivers that are wholly within it substantially undiminished, except by such drafts upon them as the guardian of the public welfare may permit." ${ }^{225}$ The Court relied in part on Geer's "preservation" rationale, ${ }^{226}$ as well as on Geer's holding that a State might qualify the property interest one receives in a resource to prevent it from becoming an object of interstate commerce. ${ }^{227}$

Like $M c C r e a d y$, Hudson County has suffered serious erosion from a doctrinal point of view. The general proposition that a State may "preserve" natural resources located within its borders by forbidding their exportation or by qualifying the property interest that private parties acquire in such resources was finally laid to rest with the overruling of Geer. While the State's alleged "ownership" of the water might have provided an independent ground for such a holding, the Supreme Court, as noted, explicitly refused to rest its decision on that ground. ${ }^{228}$ By its own terms, then, Hudson County represents a precedent of doubtful validity.

But what about its outcome? If the New Jersey statute were defended today on the ground that New Jersey's ownership interest in the water was sufficient to remove it from the rules of the privately owned resource cases, which it clearly could not survive, would the statute nevertheless withstand Commerce Clause scrutiny? I should think not. Even if a State enjoyed conventional ownership rights in a natural resource, thus implicating the rules applicable to state control of state-owned resources, it seems highly unlikely for reasons suggested above ${ }^{229}$ that an absolute bar on the exportation of the resource is the type of preference for in-state interests that might be tolerated on the basis of state ownership. But Hudson County is an easy case. ${ }^{230}$

${ }^{225} I d$. at 356.

${ }^{220}$ Ibid. See text supra, at notes 34-37.

${ }^{227} 209$ U.S. at 357. See text supra, at notes 23-33. Notwithstanding the Court's disclaimer of relying on state ownership of the resource as the basis of its decision, see text supra, at notes 222-23, its reliance on this aspect of Geer suggests that "common ownership" principles were nevertheless informing the Court's thinking.

228 The New Jersey courts, however, had done so. McCarter v. Hudson County Water Co., 70 N.J.Eq. 525 (1905), aff'd, 70 N.J.Eq. 695 (1906).

${ }^{229}$ See text supra, at notes 160-75.

${ }^{230}$ Indeed, in Carr v. City of Altus, 385 U.S. 35, aff'g, 255 F. Supp. 828 (W.D. Tex. 1966), the Court cast doubt on the holding of Hudson County by summarily affirming the decision of a three-judge federal district court which held unconstitutional a Texas statute forbidding the shipment outside the State of water 
Suppose New Jersey limited to in-state residents and businesses access to all waters in the State, subject to preexisting private rights in such waters. Would this pass constitutional muster? The issue could only be resolved by analysis of the complex and confusing problems associated with state "ownership" of water ${ }^{231}$ to determine whether the appropriate analogy for purposes of Commerce Clause analysis is to wildlife or to state lands or to something else. Again, no claim is made here to any expertise in the field of water rights. The point to be made is a narrow one that state control of water, like control of oyster beds, raises questions under the Commerce Clause that have not been answered by Hughes v. Oklaboma. Moreover, these questions, while arising in cases that can be viewed as curious relics from the distant past, may surface in the future in connection with existing state legislation that embodies their holdings. ${ }^{232}$

\section{Conclusion}

The Court's decision in Hugbes v. Oklaboma reflects and . reinforces its general approach to Commerce Clause limitations on state regulation. The interment of the artificial exception to this approach that had been associated with the notion that a State "owns" its wildlife is a sound development, ${ }^{233}$ although the result in Hughes may be questioned in light of congressional legislation

withdrawn from underground sources within the State. The district court, "[c]onsidering the statute in question only with regard to whether it regulates the transportation and use of water after it has been withdrawn from a well and becomes personal property" concluded that such water was like any other privately owned property and that the natural gas cases, see notes 123 and 125 mupra, were controlling. Id. at 839. But see West v. Kansas Natural Gas Co., 221 U.S. 229, 258-60 (1911) (distinguishing Hudson County); see generally Comment, "It's Our Water!"-Can Wyoming Constitutionally Probibit the Exportation of State Waters?, 1975 LAND \& WATER Rev. 119.

${ }^{231}$ See Trelease, Government Ownersbip and Trusteeship of Water, 45 CaLrs. L. Rev. 638 (1957).

${ }^{232}$ See, e.g., Md. Nat. Res. Code Ann. $\$ \$ 4-1003,1004(\mathrm{~b})$, considered in Lewis \& Strand, note 195 supra, at 2 nn. 3 and 4; Wyo. Stat. $\$ 41-10.5$, considered in Comment, note 230 supra.

${ }^{233}$ The common-trust doctrine has application far beyond the negative implications of the Commerce Clause, for example, as a basis for state standing to assert the common interests of its citizens in environmental and other litigation. See, e.g., Commonwealth v. S.S. Zoe Colocotroni, 456 F. Supp. 1327, 1336-37 (D.P.R. 1978). There is nothing in Hughes to suggest that these applications of the common-trust doctrine are affected by the Court's decision. 
arguably consenting to laws like Oklahoma's. ${ }^{23}$ The confidence with which the Court disposed of the controversy in Hughes, moreover, cannot obscure the significance of the underlying conflict between the nation's interest in unfettered commerce among the States and the States' interest in controlling the disposition of their natural resources, a conflict that extends far beyond the question of whether Oklahoma may keep natural minnows within its borders. Lurking behind the "fictions" of State orvnership, which the Court found so easy to abandon in Hughes, are realities of state ownership that present much harder cases.

${ }^{234}$ See text supra, at notes $20-22$. 
HeinOnline -- 1979 Sup. Ct. Rev. 941979 